Canadian

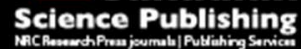

Canadian Journal of Microbiology Revue canadienne de de microbiologie

\title{
Genetic and phenotypic diversity of rhizobia nodulating Chickpea (Cicer arietinum L.) in soils from southern and central Ethiopia
}

\begin{tabular}{|r|l|}
\hline Journal: & Canadian Journal of Microbiology \\
\hline Manuscript ID & cjm-2016-0776.R2 \\
\hline Manuscript Type: & Article \\
\hline Complete List of Authors: & $\begin{array}{l}\text { Tena, Wondwosen; Debreberhan University } \\
\text { Wolde-meskel, Endalkachew; International Livestock Research Institute, } \\
\text { P.O. Box 5689, Addis Ababa } \\
\text { Degefu, Tulu; Hawassa University } \\
\text { Walley, Fran; University of Saskatchewan, Soil Science }\end{array}$ \\
\hline Keyword: & $\begin{array}{l}\text { Mesorhizobium, MLSA, Core genes, Symbiotic genes, Symbiotic } \\
\text { effectiveness }\end{array}$ \\
\hline \multicolumn{2}{|c}{} \\
\hline
\end{tabular}

SCHOLARONE

Manuscripts 


\title{
Genetic and phenotypic diversity of rhizobia nodulating Chickpea (Cicer arietinum L.) in soils from southern and central Ethiopia
}

\author{
Wondwosen Tena $^{1^{*}}$, Endalkachew Wolde-Meskel ${ }^{2}$, Tulu Degefu ${ }^{3}$, and Fran Walley ${ }^{4}$ \\ ${ }^{1}$ Debre Berhan University, Department of Plant Science, P.O. Box 445, Debre Berhan, \\ Ethiopia; \\ ${ }^{2}$ International Livestock Research Institute, P.O. Box 5689, Addis Ababa, Ethiopia; \\ ${ }^{3}$ Hawassa University, Department of Biology, P.O.Box 05; \\ ${ }^{4}$ Department of Soil Science, College of Agriculture and Bioresources, University of \\ Saskatchewan, 51 Campus Drive, Saskatoon, Canada, S7N 5A8. \\ *Author to whom correspondence should be addressed; E-Mail: wondtena@gmail.com; Tel.: \\ +251911184535 .
}

\begin{abstract}
Forty-two chickpea-nodulating rhizobia were isolated from soil samples collected from diverse agro-ecological locations of Ethiopia, and characterized based on 76 phenotypic traits. Furthermore, 18 representative strains were selected and characterized using multilocus sequence analyses (MLSA) of core and symbiotic gene loci. Numerical analysis of the phenotypic characteristics grouped the 42 strains in to four distinct clusters. The analysis of the 16S rRNA gene of the 18 strains showed that they belong to the Mesorhizobium genus. Based on phylogenetic tree constructed from the combined genes sequences ( $r e c A$, $a t p D, g \ln I I$, and $g y r B)$, the test strains were distributed into four genospecies (designated as genospecies I - IV). Genospecies I, II, and III could be classified with $M$. ciceri, M. abyssinicae, and $M$. shonense, respectively while genospecies IV might represent an unnamed Mesorhizobium genospecies. Phylogenetic reconstruction based on the symbiosis-related (nifH and nodA) genes supported a single cluster together with previously described symbiont of chickpea (M. ciceri and M. mediterraneum). Overall, our results corroborate earlier findings that Ethiopian soils harbor phylogenetically diverse Mesorhizobium species, justifying further explorative studies. The observed differences in symbiotic effectiveness indicated the potential to select effective strains for use as inoculants and to improve the productivity of chickpea in the country.
\end{abstract}

Keywords: Mesorhizobium, MLSA, Core genes, Symbiotic genes, Symbiotic effectiveness 


\section{Introduction}

Chickpea (Cicer arietinum L.) is the world's third most important food legume crop. Ethiopia ranks first in chickpea production and hectareage in Africa (FAO 2015), where it plays an important role in the local economy and contributes to sustainable agriculture. Because of higher protein contents as compared to cereals, legumes such as chickpea have attained significance for having excellent food value for the human diet, particularly for developing countries such as Ethiopia where animal protein sources are unaffordable for most people. However, the national average chickpea yield in Ethiopia is $1.7 \mathrm{t} \mathrm{ha}^{-1}$ (CSA 2013), which is far below the potential yield of $5.0 \mathrm{t} \mathrm{ha}^{-1}$, suggested by others (Keneni et al. 2011). Low soil fertility is one of the most important yield limiting factors in sub-Saharan Africa (SSA). Among essential plant nutrients, nitrogen (N) is the most important limiting nutrient for crop production in Ethiopia. Use of nitrogenous fertilizers is limited because it is poorly accessible and costly to smallholder farmers (Yanggen et al. 1998). Thus, increased use of legume crops is a viable alternative due to their ability to fix atmospheric $\mathrm{N}$ in symbiotic associations with rhizobia, forgoing the need for inorganic $\mathrm{N}$ inputs. The successful production of legumes including chickpea thus depends on the availability of compatible rhizobia in the soil with superior symbiotic performance.

Rhizobia are soil-inhabiting Gram-negative bacteria that form root nodules on legume plants and exist as intracellular symbionts within the developed nodules, converting atmospheric $\mathrm{N}$ into ammonia for assimilation by the plant in exchange for plant-derived organic acids (Abaidoo et al. 1990, Sprent 2007). Chickpea has been considered specific for its rhizobial requirement (Gaur and Sen 1979) nodulating with only two species, Mesorhizobium ciceri and Mesorhizobium mediterraneum (Nour et al. 1994a, 1994b, 1995). However, recently use of molecular methods and characterization of samples from more geographical locations revealed that chickpea nodulating rhizobia belong to several species within the genus Mesorhizobium (Alexandre et al. 2009; Laranjo et al. 2012; Rai et al. 2012). Importantly, many current chickpea producing areas may be devoid of rhizobia capable of nodulating chickpea. For example, until chickpea was introduced in Western Canada in the early 1990's, soils there contained no indigenous rhizobia capable of nodulating chickpea (Kyei-Boahen et al. 2002). While chickpea production has increased in this area, only introduced rhizobia are able to nodulate chickpea, making the choice of rhizobial strain particularly important as both the crop and the soil microbial community are effectively inoculated by the introduced strains. In contrast, it is presumed that soils in Ethiopia support a vast array of rhizobial 
strains capable of nodulating chickpea, reflecting the long history of cultivation of chickpea landraces and likely co-evolution of the symbionts.

Modern bacterial taxonomy is based on the integration of phenotypic and genotypic data for a more stable classification (Vandamme et al. 1996; Zakhia and De Lajudie 2001). Phenotypic studies are necessary for characterization and selection of rhizobial strains adapted to marginal edaphoclimatic conditions, and to provide preliminary information about their genetic diversity (Howieson and Dilworth 2016; Zahran et al. 2003). Sequence analysis of the 16S rRNA gene has been used as a regular protocol for bacterial taxonomic study. Rhizobial genomes often carry several copies of the 16S rRNA gene; however, they usually are 100\% similar. The largest limitation of using the $16 \mathrm{~S}$ rRNA gene in rhizobia taxonomy is its low discrimination level for closely related species (Acinas et al. 2004; van Berkum et al. 2006). To overcome these drawbacks, protein-coding genes have been proposed as alternative phylogenetic markers to discriminate between closely related species (Stackebrandt et al. 2002). These genes have a faster rate of evolution than the 16S rRNA gene, but are conserved enough to retain genetic information useful for taxonomy purposes. Consequently, new techniques such as Multilocus Sequence Analysis (MLSA) based on the analysis of several housekeeping genes have been applied in phylogenetic analyses and identification of concrete groups of rhizobia (Menna et al. 2009; Rivas et al. 2009; Wang et al. 1998). Besides these housekeeping genes, other genes involved in the legume symbiosis called "accessory" genes are commonly included in rhizobial species description and in some MLSA analyses (Rivas et al. 2009).

Ethiopia has a large biodiversity of rhizobial resources (Wolde-meskel 2007); however, only a few of them have been extensively explored using a molecular approach (Wolde-meskel et al. 2005; Degefu et al. 2011; Asrese et al. 2012; Asrese et al. 2013; Degefu et al. 2013), and the genetic diversity of chickpea nodulating rhizobia remains largely unexplored. In order to improve the beneficial effect of chickpea inoculation, it is important to determine the characteristics of the indigenous rhizobial population. Therefore, the aims of the experiments reported in this paper were: (i) to study the symbiotic and phenotypic characteristics of chickpea nodulating rhizobia isolated from soil samples collected from chickpea growing locations in southern and central Ethiopia; and ii) to evaluate genetic diversity among the chickpea rhizobial strains. For this purpose we determined the phylogeny of housekeeping genes coding for recombination protein (rec $A)$, 16S rRNA, glutamine synthase II $(g \ln I)$, ATP synthase beta subunit $(a t p D)$ and DNA gyrase subunit B (gyrB). The phylogeny of symbiotic genes for nodulation (nodA) and nitrogen fixation (nifH) also were studied for the test strains. 


\section{Materials and methods}

\section{Bacterial strains and culture conditions}

The 42 rhizobial isolates (Table 1) used in this study were isolated from root nodules of chickpea, Cicer arietinum (cultivar Nattoli) grown in soil samples collected from chickpea growing farmers' fields at diverse agro-ecological locations in southern and central Ethiopia (Fig. 1). These areas have a history of chickpea cultivation that extends for centuries, and to our knowledge they have never been inoculated with rhizobial strains. Rhizobia were isolated, purified and cultivated on Yeast extract Mannitol Agar (YMA) following Vincent (1970). Primary isolates from YMA containing Congo Red (CR) plates were re-streaked on YMA containing $25 \mu \mathrm{g} \mathrm{mL}{ }^{-1}$ Bromothymol Blue (BTB), $25 \mu \mathrm{g} \mathrm{mL}^{-1} \mathrm{CR}$ and Pentose Glucose Agar containing $25 \mu \mathrm{g} \mathrm{mL}^{-1}$ Bromocresol Purple (PGA-BCP) and incubated at $28^{\circ} \mathrm{C}$ for differentiation purposes (Howieson and Dilworth 2016). All strains were stored in $15 \%(\mathrm{v} / \mathrm{v})$ glycerol at $80^{\circ} \mathrm{C}$.

$<<$ Insert Figure 1 here $>>$

$<<$ Insert Table 1 here $>>$

\section{Symbiotic traits}

To assess infectivity and effectiveness in fixing atmospheric N, each strain was grown in Yeast extract Manitol Broth (YMB) to the logarithmic phase $\left( \pm 10^{9}\right.$ cell $\left.\cdot \mathrm{ml}^{-1}\right)$ and aseptically inoculated on germinated seeds of chickpea planted in modified Leonard jars containing sterilized and $\mathrm{N}$-free growth media (Howieson and Dilworth 2016). The experiment was carried out with three replicates using a randomized complete design. As controls, each block contained two jars ( $\mathrm{N}$ free and with $\mathrm{N}$ ) with non-inoculated seedlings. The seedlings were watered weekly with sterile, one-quarter strength Jenson's modified N-free nutrient solution and with sterilized distilled water as necessary, according to Howieson and Dilworth (2016). Furthermore, the positive control (with N) received weekly additions of $0.5 \%(\mathrm{w} / \mathrm{v}) \mathrm{KNO}_{3}$ as a $\mathrm{N}$ source. Plants were maintained in a greenhouse and harvested 45 days after planting and nodule number, nodule dry weight, and shoot dry biomass were recorded. The plant shoot samples were oven dried at $70^{\circ} \mathrm{C}$ to a constant weight and ground to pass through a 2 mm sieve. Nitrogen accumulation in the plant shoot (percent N) was determined using a LECO CNS2000 carbon, nitrogen, and sulfur analyzer. The data were analyzed by one-way analysis of variance 
using the general linear model procedure of the SAS software package (SAS/STAT; version 9.3) and mean values were separated according to Duncan's multiple range test at $p=0.05$ (SAS Institute 2012). The percent symbiotic effectiveness (SE) of the isolates was expressed as a percentage of the shoot dry biomass of each treatment compared with the shoot dry biomass of the positive control (with N). Finally, the SE values of the isolates were rated as highly effective, $>80 \%$; effective, $50-$ $80 \%$; poorly effective, 35-50\%; or ineffective, $<35 \%$ (Purcino et al. 2000).

\section{Physiological and biochemical tests}

Except for carbohydrate and $\mathrm{N}$ assimilation, all the following tests were carried out in triplicate on YMA plates. The plates were divided into 64 equal parts. Each square was spot-inoculated with 10 $\mu \mathrm{L}$ of the strain culture previously grown on YMB to the exponential phase $\left( \pm 10^{9} \mathrm{cells} \cdot \mathrm{mL}^{-1}\right)$. Inoculated plates were incubated at $28^{\circ} \mathrm{C}$ and, after 7 days, the growth of colonies was monitored visually (Howieson and Dilworth 2016). The following reference strains were subjected to phenotypic characterization together with the test strains to elucidate the relatedness with the reference strains: M. loti HAMBI $\left(1129^{\mathrm{T}}\right.$ ), Ensfer meliloti (HAMBI 2148 ${ }^{\mathrm{T}}$ ), Rhizobium leguminosarum (HAMBI12 ${ }^{\mathrm{T}}$ ), Bradyrhizobium japonicum (HAMBI 2314 ${ }^{\mathrm{T}}$ ), M. mediterraneum (HAMBI 2096 ${ }^{\mathrm{T}}$ ), and Rhizobium huautlense (HAMBI 2409 ${ }^{\mathrm{T}}$ ).

\section{Physiological Characteristics}

Bacterial growth at different temperatures was determined on YMA plates inoculated as described above and incubated at the following temperatures: $5^{\circ} \mathrm{C}, 15^{\circ} \mathrm{C}, 20$ to $30^{\circ} \mathrm{C}, 35^{\circ} \mathrm{C}, 40^{\circ} \mathrm{C}$, and $45^{\circ} \mathrm{C}$ (Maatallah et al. 2002). The isolates were tested for their tolerance to salinity on YMA media supplemented with $\mathrm{NaCl}$ at concentrations of 1\%, 2\%, 3\%, 4\%, and 5\% (w/v) (Amarger et al. 1997). The ability of the isolates to grow on acidic and alkaline media were tested by inoculating them onto YMA with the $\mathrm{pH}$ adjusted to $4.0,4.5,5.0,5.5,8.0,8.5,9.0,9.5$ or 10.0 with a $10 \%$ sterile solution of $\mathrm{HCl}$ or $\mathrm{NaOH}$ (Amarger et al. 1997). 


\section{Intrinsic antibiotic and heavy metal resistance}

The intrinsic antibiotic and heavy metal resistances of the isolates were tested on YMA with various concentrations of antibiotics or metal compounds incorporated. The stock solutions of the antibiotics or heavy metals were sterilized using $0.2 \mu \mathrm{m}$ membrane filters and added to YMA at $55^{\circ} \mathrm{C}$ via filter paper with a Luer-Lock system using hypodermal syringes in a laminar hood flow. The antibiotics used were as follows: chloramphenicol (5 and $15 \mu \mathrm{g} \cdot \mathrm{mL}^{-1}$ ), erythromycin (10 and 20 $\left.\mu \mathrm{g} \cdot \mathrm{mL}^{-1}\right)$, streptomycin $\left(40\right.$ and $\left.80 \mu \mathrm{g} \cdot \mathrm{mL}^{-1}\right)$, spectinomycin $\left(250\right.$ and $\left.500 \mu \mathrm{g} \cdot \mathrm{mL}^{-1}\right)$, kanamycin $(15$ $\left.\mu \mathrm{g} \cdot \mathrm{mL}^{-1}\right)$, lincomycin $\left(100 \mu \mathrm{g} \cdot \mathrm{mL}^{-1}\right)$, trimethoprim $\left(200 \mu \mathrm{g} \cdot \mathrm{mL}^{-1}\right)$, neomycin $\left(5\right.$ and $\left.20 \mu \mathrm{g} \cdot \mathrm{mL}^{-1}\right)$, and novobiocin $\left(5 \mu \mathrm{g} \cdot \mathrm{mL}^{-1}\right)$. Similarly, the heavy metals used were $\mathrm{MnSO}_{4} \cdot \mathrm{H}_{2} \mathrm{O}\left(500 \mu \mathrm{g} \cdot \mathrm{mL}^{-1}\right)$, $\mathrm{AlCl}_{3} \cdot 6 \mathrm{H}_{2} \mathrm{O}\left(500 \mu \mathrm{g} \cdot \mathrm{mL}^{-1}\right), \mathrm{Pb}\left(\mathrm{CH}_{3} \mathrm{COOH}\right) .3 \mathrm{H}_{2} \mathrm{O}\left(500 \mu \mathrm{g} \cdot \mathrm{mL}^{-1}\right), \mathrm{CoSO}_{4} \cdot 7 \mathrm{H}_{2} \mathrm{O}\left(100 \mu \mathrm{g} \cdot \mathrm{mL}^{-1}\right)$, $\mathrm{CuCl}_{2}\left(100 \mu \mathrm{g} \cdot \mathrm{mL}^{-1}\right)$, and $\mathrm{ZnCl}_{2}\left(500 \mu \mathrm{g} \cdot \mathrm{mL}^{-1}\right)$ (Howieson and Dilworth 2016). Strains were considered resistant when growth occurred, and sensitive when no growth was detected.

\section{Carbon source utilization}

The following carbon sources were used to determine whether they could be used as the sole carbon source for the isolates following Howieson and Dilworth (2016): D-trehalose, dextrin, Dmaltose, sucrose, D-xylose, D-rhamnose, D-raffinose, sorbitol, citric acid, dulcitol, L-arabinose, malonic acid, D-fructose, xylitol, D-mannitol, myo-inositol, D-galactose, D-mannose, and glycine. Carbohydrate solution $[10 \mu \mathrm{L}$ of a $10 \%(\mathrm{~m} / \mathrm{v})$ solution in distilled water] was prepared in sterilized plastic vials. Heat stable carbon sources (fructose, glucose, sucrose, lactose and mannitol) were added to the carbohydrate-free basal medium (essentially similar to YM with a concentration of yeastextract reduced to $0.05 \mathrm{~g} \cdot \mathrm{L}^{-1}$ ) at a final concentrations of $1 \mathrm{~g} \cdot \mathrm{L}^{-1}$ and autoclaved together with the media. The other heat labile carbon sources were sterilized using $0.2 \mu \mathrm{m}$ mesh sterile filter papers with a Luer-Lock system and added to the basal medium at $55^{\circ} \mathrm{C}$ aseptically. The solutions were then aseptically dispensed into sterile petri dishes and allowed to solidify in the hood.

\section{Nitrogen source utilization}

The following $\mathrm{N}$ sources were tested as sole $\mathrm{N}$ sources for the isolates according to Amarger et al. (1997): D-serine, L-histidine, L-pyroglutamic acid, L-phenylalanine, L-proline, uridine, thymidine, inosine, L-arginine, L-leucine, L-aspartic acid, L-glutamic acid, L-threonine, L-alanine, L-asparagine, 
and L-isoleucine. These $\mathrm{N}$ sources were added to a basal medium at a final concentration of $0.5 \mathrm{~g} \cdot \mathrm{L}^{-1}$. The basal medium was adjusted to be $1 \mathrm{~g}$ of $\mathrm{K}_{2} \mathrm{HPO}_{4}, 1 \mathrm{~g}$ of $\mathrm{KH}_{2} \mathrm{PO}_{4}, 0.01 \mathrm{~g}$ of $\mathrm{FeCl}_{3} .6 \mathrm{H}_{2} \mathrm{O}, 0.2 \mathrm{~g}$ of $\mathrm{MgSO}_{4} \cdot 7 \mathrm{H}_{2} \mathrm{O}, 0.1 \mathrm{~g}$ of $\mathrm{CaCl}_{2}, 1 \mathrm{~g}$ of $\left(\mathrm{NH}_{4}\right)_{2} \mathrm{SO}_{4}$ and $15 \mathrm{~g}$ of agar per liter of distilled water.

\section{Phosphate solubilization}

The basal medium $\left(10 \mathrm{~g} \cdot \mathrm{L}^{-1}\right.$ glucose, $\quad 0.5 \mathrm{~g} \cdot \mathrm{L}^{-1}$ yeast-extract, $\quad 0.1 \mathrm{~g} \cdot \mathrm{L}^{-1} \quad \mathrm{CaCl}_{2}, \quad 0.25 \mathrm{~g} \cdot \mathrm{L}^{-1}$ $\mathrm{MgSO}_{4} \cdot 7 \mathrm{H}_{2} \mathrm{O}$, and $15 \mathrm{~g} \cdot \mathrm{L}^{-1}$ agar dissolved in distilled water) was used to test the phosphate solubilizing ability of the isolates. The medium was supplemented with $2.5 \mathrm{~g} \cdot \mathrm{L}^{-1}$ of $\mathrm{Ca}_{3}\left(\mathrm{PO}_{4}\right)_{2}$ as a source of phosphate. The $\mathrm{pH}$ of the medium was adjusted to 7.2 before autoclaving (Alikahani et al. 2006). The appearance and formation of the clear zone around the colony was checked within 7 to 10 days of inoculation (Xie et al. 2009). Isolates that formed clear zones around the colony were considered phosphate solubilizers.

\section{Numerical analysis}

Traits were coded 1 for positive and 0 for negative. The final matrix contained 42 isolates, 6 reference strains (altogether 48), and 76 traits. A computer cluster analysis of 76 phenotypic variables was carried out using a similarity coefficient and a dendrogram was constructed by the unweighted pair group method with average (UPGMA) clustering with the NTSYSpc21 program.

\section{DNA preparation}

Total genomic DNA was isolated from $3 \times 1.5 \mathrm{~mL}$ cultures using the procedure described previously by Boom et al. (1990) with a slight modification using diatomaceous earth or a Celite analytical filter aid as a DNA binding solid support (Terefework et al. 2001).

\section{PCR amplification and gene sequencing}

The following genes were studied: $16 \mathrm{~S}$ rRNA, partial internal sequences of protein coding housekeeping genes (recA, gyrB, atpD, and $g \ln I)$, and the symbiosis related genes (nodA and nifH). The partial 16S rRNA gene was amplified and sequenced using the primers fD1 and rD1 as described previously Weisburg et al. (1991). PCR amplification and sequencing of partial rec $A$ and atpD genes were undertaken according to Gaunt et al. (2001), and glnII and gyrB gene amplification and 
sequencing were as carried out following the PCR conditions previously specified (Martens et al. 2008). Partial amplification and sequencing of the symbiotic gene, $\operatorname{nod} A$, was carried out as previously described (Laguerre et al. 2001). For amplification and sequencing of the partial nifH gene sequence, primers and PCR condition specified by Rivas et al. (2002) were used.

\section{Phylogenetic data analysis}

The quality of the sequences was checked and edited using BioEdit 7.2.5 (Hall 2004). For preliminary identification, the $16 \mathrm{~S}$ rRNA gene sequences of the test strains were compared to the Genbank database using nucleotide BLAST. The 16S rRNA sequences obtained from the 18 rhizobia strains used in the present study were compared with those of Mesorhizobium reference strains available in the GenBank database. Multiple nucleotide alignments for the test isolates and reference species in the genus Mesorhizobium were carried out using the CLUSTAL W program (Thompson et al. 1994) from MEGA version 6.0 (Tamura et al. 2013). Phylogenetic trees were constructed using the neighbor-joining method with Kimura's two-parameter model, nucleotide distances and discarding positions with gaps in any sequence. The robustness of the tree topology was calculated from bootstrap analysis with 1000 replications of the sequences for neighbor-joining. The percentage similarity of the genes was estimated using the Kimura-2 distance matrix correction model as implemented in MEGA version 6 (Tamura et al. 2013).

\section{Results}

\section{Isolation and symbiotic effectiveness test on sand culture}

Forty-two chickpea isolates formed nodules when re-inoculated on host plants using sterile sand culture under controlled environmental conditions. All 42 isolates were Gram-negative, rod-shaped bacteria that did not grow on Peptone Glucose Agar containing Bromo Cresol Purple (PGA-BCP) and absorbed Congo Red (CR) on YEM-CR media (data not shown). Furthermore, all isolates turned the Bromo Thymol Blue (BTB)-YEM media from moderately yellow to deep yellow.

Symbiotic effectiveness of the test strains showed considerable variations when inoculated to the host plant (Chickpea, var. Nattoli). The uninoculated control was not nodulated. The test strains of chickpea rhizobia showed great variation in their ability to fix atmospheric $\mathrm{N}$ and consequent ability to enhance shoot dry weight, shoot $\mathrm{N}$ uptake, nodule number, and nodule dry weight per plant 
$(\mathrm{p}<0.001$; Table 2). The highest shoot dry matter accumulation was recorded from plants inoculated with the isolate CP41 followed by plants treated with isolates CP97, CP105, and CP08, with shoot dry matter accumulation of $0.98,0.83,0.81$ and $0.81 \mathrm{~g} \cdot \mathrm{plant}^{-1}$, respectively. The lowest dry mass was recorded from plants inoculated with isolates CP65, CP84, and CP109, which all yielded $0.33 \mathrm{~g} \cdot \mathrm{plant}^{-}$ 1. Similarly, the effect of indigenous rhizobial strains on shoot $\mathrm{N}$ uptake varied in the range of 7.8 (CP65) to 41.8 (CP41) $\mathrm{mg} \cdot$ plant $^{-1}$. The relative differences of $\mathrm{N}$ accumulation increase in shoot by CP41, CP97, CP105 and CP08 strains were 98, 78, 76 and 75\%, respectively over the uninoculated N fertilized control.

$<<$ Insert Table 2 here $>>$

The mean nodule number per plant varied from 17 to 60, which were induced by isolates CP74 and CP151, respectively. Despite the large number of nodules per plant recorded by isolate CP151, this isolate had low symbiotic effectiveness (67\%) as shown in Table 2. The highest nodule dry weight of $208 \mathrm{mg} \cdot$ plant $^{-1}$ was recorded from plants inoculated with isolate CP41, whereas the lowest nodule dry weight of $41 \mathrm{mg} \cdot$ plant $^{-1}$ was shown by the host inoculated with isolate CP140. The relative effectiveness, expressed in percent of the N-fed control, showed that isolates CP08, CP41, CP97, CP105 and CP133 were the most efficient, with more than $80 \%$ dry matter yield relative to the uninoculated N-fed control while CP65, CP84 and CP109 were the least efficient with only 33\% effectiveness.

\section{Physiological traits and numerical analysis}

The phenotypic traits of the 42 chickpea rhizobia are summarized in Table S1 and S2. The optimum temperature for growth of all isolates was in the range 20 to $35^{\circ} \mathrm{C}$. Below and beyond this range, the isolates showed variations in their growth. The salt inhibitory concentrations varied among strains. All bacterial isolates survived at $1 \% \mathrm{NaCl}$, and $85.7 \%$ of the isolates survived at $2 \% \mathrm{NaCl}$. However, at higher concentrations, the percentage of tolerant strains decreased rapidly and only two strains showed a moderate growth at $4 \%$ and $5 \% \mathrm{NaCl}$. All isolates grew at $\mathrm{pH}$ values ranging between 8 and 8.5. The reference strains were very sensitive to extreme temperatures, high $\mathrm{NaCl}$ concentrations, and extremes of $\mathrm{pH}$ as compared to the indigenous strains (data not shown). All tested strains grew on trehalose, sucrose, galactose, glucose, mannitol, inosine, histidine, asparagine, glutamic acid, threonine, alanine, uridine, and leucine. None of the strains utilized citric acid. The 
evaluation of intrinsic resistance to antibiotics (according to their concentrations) of chickpea nodulating rhizobia showed that all of the tested isolates exhibited high resistance to erythromycin and neomycin. All tested strains were found to be sensitive to streptomycin, spectinomycin, and lincomycin, and thus were not able to grow. All test strains were found to be sensitive to zinc.

The dendrogram obtained from the computer numerical analysis of 76 phenotypic traits of the 42 chickpea nodulating rhizobia including the six reference strains showed that they could be grouped into at least four clusters at 30\% similarity level (supplemental Fig. 1). Cluster I was the largest with 30 test strains originating from various locations (Table 1) and clustered independently by excluding the reference species. Cluster $\mathrm{I}$ is again grouped in to 8 sub clusters at $75 \%$ similarity level. The majority of strains in Cluster I was able to grow at $\mathrm{pH}$ ranging between 5 and 9.5, at temperatures between $10^{\circ} \mathrm{C}$ and $35^{\circ} \mathrm{C}$, and tolerated $\mathrm{NaCl}$ concentrations ranging between $1 \%$ and $2 \%$. The growth of these isolates was fully inhibited by kanamycin, streptomycin, ampicillin, chloramphenicol, spectinomycin, nickel, zinc, aluminum, cobalt, and lead, but they were insensitive to nalidixic acid, mercury, and manganese. Most of inorganic phosphate-solubilizer (67\%) strains were observed in this cluster. Regarding carbohydrate assimilation, these bacteria were able to metabolize a wide range of carbon substrates.

Cluster II has only three isolates (CP98, CP125, and CP136) and exhibited similar characteristics to the reference strains $M$. loti and M. mediterraneum. Unlike strains of other clusters, they could not tolerate a $\mathrm{NaCl}$ concentration greater than $2 \%$ nor extreme temperature. The majority of Cluster II strains were able to grow with in a $\mathrm{pH}$ range between 4 and 8.5. It seems that this group resists acidic conditions. Inorganic phosphate-solubilizing activity was not observed in this cluster. The growth of these isolates was fully inhibited by raffinose and malonic acid but they grew well in most carbohydrate, $\mathrm{N}$ and antibiotic sources.

Cluster III consists of six isolates. They have distinct characteristics in that they tolerate a $5 \%$ $\mathrm{NaCl}$ concentration and most of them are capable of solubilizing inorganic phosphate. Cluster III isolates exhibited similar characteristics to the reference strains Rhizobium leguminosarum and Rhizobium huautlense. Most of the strains of Cluster III grew well in most carbohydrate, $\mathrm{N}$ and antibiotic sources. They were resistant to $\mathrm{Al}$ and $\mathrm{Co}$ but sensitive to $\mathrm{Zn}$ and $\mathrm{Cu}$. Cluster IV has only three isolates (CP74, CP99, and CP100). These were sensitive to low and high $\mathrm{pH}$ and temperature extremes, as well as high salinity. They also were sensitive to kanamycin and copper. Cluster IV was also characterized by the ability to solubilize inorganic phosphate. Similar to the other clusters most of the strains of Cluster IV grew well in most carbohydrate and $\mathrm{N}$ sources and tolerated most 
antibiotic sources. The two reference strains (Ensifer meliloti and Bradyrhizobium japonicum) were clustered alone on the dendrogram.

\section{Genetic diversity and identification}

Of the 42 test stains, 18 representative strains based on phenotypic characteristic and geographical location of soil sampling sites were selected (Table 1) and characterized using multilocus sequence analyses (MLSA) of 16S rRNA, core (recA, atpD, glnII, and gyrB) and symbiotic (nodA and nifH) genes loci. The identification process started with the sequencing of the partial16S rRNA gene (1322 - 1362bp). For each gene, sequence data were aligned and used to infer phylogenetic trees and to compare the placement of the test strains with respect to currently (at the time of writing this manuscript) designated Mesorhizobium reference species.

\section{$16 S$ rRNA gene sequence analysis}

The partial 16S rRNA gene sequences of the 18 chickpea rhizobia test strains were obtained and compared with Mesorhizobium strains available in the GenBank database. In the 16S rRNA gene phylogenetic tree, 18 test strains belonged to the branch defining the genus Mesorhizobium (Fig. 2a). The phylogenetic tree built with the 16S rRNA sequences split the Mesorhizobium test strains in three groups. The first group comprised three test strains grouped with $M$. ciceri USDA3383 and $M$. cantuariense ICMP 19515 with sequence similarity of 100\%. The second group included eight strains showing closer relation with $M$. shonense HAMBI 3295 with sequence similarity of $99.8 \%$ and the third group included seven test strains showing closer relation with M. plurifarium LMG 11892 with sequence similarity of $99.6 \%$. The taxonomic positions of the strains were further investigated by rec $A$, atpD, glnII, and $g y r B$ gene sequence analysis.

$<<$ Insert Figure 2 here $>>$

\section{Analysis of concatenated gene sequences}

Phylogenetic trees were constructed based on the combined $\operatorname{rec} A$, atpD, glnII and gyr $B$ gene sequences (in total 1635bp in length). The phylogenetic tree of concatenated genes (Fig. 2b) generated from sequence alignments of the test strains and the described reference species, revealed 
four clusters with high bootstrap support (99\% to $100 \%)$ at each branch. The different genospecies were placed into separate four clades within Mesorhizobium genus. Genospecies I comprising CP123, CP125 and CP148 were found to be closely associated with previously described microsymbiont of chickpea, M. ciceri USDA3383 with Average Nucleotide Identity (ANI value) of 98.2\%. Genospecies II comprising two strains (CP41 and CP49) were closely related to the M. abyssinicae type strain HAMBI 3306 (one of the three described new species from Ethiopia) with ANI value of 98.7\%. Genospecies III, containing six strains (CP08, CP10, CP12, CP30, CP51, and CP69), were closely related to type strains M. shonense HAMBI 3295 (96.3\% ANI) and M. hawassense HAMBI 3301 (94.1\% ANI). Genospecies IV contains seven strains (CP84, CP98, CP105, CP130, CP134, CP136 and CP151). The phylogenetic analyses based on concatenated genes identified $M$. plurifarium LMG 11892 to be the closest related type strain to genospecies IV, with ANI value that did not exceed $94 \%$.

\section{Analysis of individual house-keeping genes}

The phylogenetic trees of the individual house-keeping genes (Fig. 3 a-d) generated from sequence alignments of the test strains and the described reference species revealed that the 18 isolates from Ethiopian soils group in four different clusters. The lengths of the alignments were $435 \mathrm{bp}, 490 \mathrm{bp}$, $616 \mathrm{bp}$ and $750 \mathrm{bp}$ for $\operatorname{rec} A$, $a t p D, g \ln I$, and $g y r B$, respectively. In the individual housekeeping phylogenetic trees, in agreement with the concatenated gene phylogeny, the test strains were consistently grouped into four separate clades (I-IV) within the Mesorhizobium genus. In general, the tree topologies for all house-keeping genes, and thus the placement of the test strains within the trees, were consistent for the four house-keeping genes ( $\operatorname{rec} A$, atpD, $g \ln I I$ and $g y r B)$. With respect to the $r e c A$, atpD, glnII and $g y r B$ genes sequences, the test strains within genospecies I were found to be closely associated with type strain M. ciceri (either USDA3383 or HAMBI 1750) with sequence similarity of $97.7 \%, 98.31 \%, 96.6 \%$, and $100 \%$, respectively. Genospecies I were closely related to M. cantuariense ICMP 19515 for recA and glnII with sequences similarity of $95.3 \%$ and $96.7 \%$, respectively.

$<<$ Insert Figure 3 here $>>$

Genospecies II were closely related to the M. abyssinicae type strain HAMBI 3306 based on recA, $a t p D, g \ln I I$, and $g y r B$ gene with sequence similarity of $99.7 \%, 99.5 \%, 99.3 \%$, and $97.1 \%$, 
respectively. Genospecies III were closely related to $M$. hawassense (HAMBI 3301) for recA and $a t p D$ with sequences similarity of $94.0 \%$ and $95.5 \%$, respectively. Meanwhile it showed a close phylogenetic relatedness to $M$. shonense for $g \ln I I$ and $g y r B$ with sequences similarity of $95.2 \%$, and 99.1\%, respectively. Similarly, genospecies III was clustered with M. hawassense for glnII with sequences similarity of $94.0 \%$. The phylogenetic analyses based on recA ( $96 \%$ similarity), atpD (96.6\% similarity), glnII (92.5\% similarity) and $\operatorname{gyr} B(91 \%$ similarity) genes identified $M$. plurifarium LMG 11892 to be the most closely related reference species to genospecies IV.

\section{Phylogeny of symbiotic genes}

The nucleotide sequences of about $600 \mathrm{bp}$ for $n o d A$ and $400 \mathrm{bp}$ for nifH genes were obtained for 18 test strains that belonged to the genus Mesorhizobium. The nodA and nifH phylogenetic trees are presented in Fig. 4a and b. The grouping of the strains on the trees generated from these genes was different from those of the core genes. In the $\operatorname{nod} A$ tree, the entire group of test strains were placed into one well-supported (100\% bootstrap value) closely related monophyletic clade along with previously described symbionts of chickpea, $M$. ciceri (UPM-Ca $\left.7^{\mathrm{T}}\right)(100 \%$ sequence similarity) and M. mediterraneum (UPM-Ca36 $\left.{ }^{\mathrm{T}}\right)(99.8 \%$ similarity). Similarly, in the nifH phylogenetic tree all test strains were tightly clustered into a single clade with the $M$. ciceri (UPM-Ca7 ${ }^{\mathrm{T}}$ ) and $M$. mediterraneum (UPM-Ca36 ${ }^{\mathrm{T}}$ ) type strains identified to be the closest neighbors $(100 \%$ sequence similarity to both).

$<<$ Insert Figure 4 here $>>$

\section{Discussion}

The results obtained from Gram staining, growth on YMA-CR medium and PGA-BCP medium confirmed the standard cultural and morphological characteristics of rhizobia. Furthermore, all isolates turned the BTB-YEM media from moderately yellow to deep yellow, indicating the acidproducing ability of the isolates, which is a common characteristic of fast growing Mesorhizobium species. In view of this characteristics feature, we further characterized the test strains using physiological and biochemical tests. 


\section{Physiological characteristics and numerical analysis}

Physiological and biochemical studies are the basis for detailed polyphasic taxonomy and have been used to make taxonomic analysis of strains belonging to the family rhizobiaceae (Zhang et al. 1991). Phenotypic characteristics including temperature and $\mathrm{pH}$ profiles are useful parameters to characterize new test strains within the family rhizobiaceae, as these parameters were shown to have a great effect on rhizobial growth and symbiotic performance (Maâtallah et al. 2002; Zahran 1999). The test strains showed differences in terms of temperature and $\mathrm{pH}$ (Table S1). A similar wide variation in phenotypic characteristic has been reported for chickpea rhizobial isolates from different countries including Ethiopia (Alexandre et al. 2009; Jida and Assefa 2012; Maâtallah et al. 2002; Rai et al. 2012; Romdhane et al. 2009). The Ethiopian chickpea nodulating strains were able to use several compounds as sole $\mathrm{C}$ and $\mathrm{N}$ sources and were variable in their response to different antibiotic and heavy metal resistance. The new strains, which were shown to utilize several $\mathrm{C}$ and $\mathrm{N}$ sources, with their abilities to resist different levels of antibiotics and heavy metals, can be considered promising candidates for inoculant development in areas where $\mathrm{C}, \mathrm{N}$, antibiotics and heavy metals are limiting factors. However, phenotypic characterization provided only an initial insight into the diversity of the new strains and molecular techniques should be employed to elucidate their exact phylogenetic positions with respect to the reference species within the genus Mesorhizobium.

\section{The chickpea microsymbionts represent four Mesorhizobium genospecies}

Phylogenetic analyses of multi-genes found on chromosomes can clarify bacterial relationships better than the analysis of a single locus (Farida et al. 2009; Rivas et al. 2009). The phylogenetic analyses based on 16S rRNA gene sequences indicated that the rhizobial strains nodulating chickpea in Ethiopia were distributed under the genus Mesorhizobium. These results were consistent with previous reports that showed chickpea rhizobia were more closely related to Mesorhizobium species (Jarvis et al. 1997; Kim et al. 2014; Laranjo et al. 2012; Rai et al. 2012). Previously, bacteria that could establish an effective symbiosis with chickpeas were considered a single group because of the specificity for the plant host (Gaur and Sen 1979), growth characteristics, and polymorphism of nifH genes (Cadahia et al. 1986). Later, based on a genotypic and phenotypic diversity studies, Nour et al. (1994a, 1994b, 1995) identified and proposed two new genomic species: Mesorhizobim ciceri and Mesorhizobium mediterraneum. Traditionally, chickpea has been considered as restrictive host for nodulation (Broughton and Perret 1999) nodulating with only these two species. However, recent 
phylogenetic studies on isolates from different geographical locations has shown that other species of Mesorhizobium may effectively nodulate the legume including M. tianshanense, M. amorphae, $M$. loti, M. huakuii, M. opportunistum and M. muleiense (Laranjo et al. 2004, 2008; Rivas et al. 2007; Suneja et al. 2016). In our study, we demonstrated that even within the relatively small sampling of the collection that were analyzed, the chickpea nodulating strains in Ethiopia represented four unique taxonomic positions in this genus, where only three strains were closely related to $M$. ciceri and no isolates grouped with M. mediterraneum. This observation justifies further exploration of the region for new chickpea nodulating strains.

Based on the concatenated genes phylogenetic tree (including $r e c A$, atpD, glnII, and gyr $B$ ), strains in genospecies I, II, and III could be classified with M. ciceri (De Lajudie et al. 1998), M. abyssinicae, and M. shonense, (Degefu et al. 2013). In all cases, the ANI values between the three groups and the reference species was higher than the cut off value (96\%) proposed by Konstantinidis et al. (2006). However, we propose genospecies IV to be unnamed Mesorhizobium genospecies because in all cases, the ANI value between genospecies IV and the defined species of Mesorhizobium was found to be lower than 96\% (Konstantinidis et al., 2006) for species identity. In our analysis, strains belonging to a single species (i.e., genospecies IV), in addition to having high intra-species sequence identity (ANI values), formed separate and highly supported monophyletic groups, distinct from the reference Mesorhizobium species. However, the placements of genospecies IV on the phylogenetic tree varied depending on the different housekeeping genes considered. Horizontal gene transfer and subsequent recombination may be a possible explanation for the inconsistent placement of this genospecies (Acinas et al. 2004; van Berkum et al. 2006). This indicated that analysis of more variable housekeeping genes could give a better correlation with the 96\% ANI value as suggested by Martens et al. (2008). In our analysis, a clear relationship was detected between the grouping of the strains and their geographic origins. Thus, genospecies I and IV are mainly from central Ethiopia, whereas genospecies II and III are from southern Ethiopia, indicating the possibility that soils at different geographic locations may harbor different population of chickpea nodulating rhizobia.

\section{Symbiosis-related gene: implication on host range}

In this study, nodA and nifH genes were analyzed in order to determine the identity of the symbiosis-related genes and the diversity of chickpea nodulating strains in terms of these genes. 
Irrespective of their chromosomal backgrounds, the designated genospecies in this study shared high sequence similarities for their nodA and nifH genes among themselves and the two defined Mesorhizobium species as references. For example, phylogenetic analyses based on nodA genes revealed that the new test strains showed close resemblance to the previously described symbionts of chickpea, M. ciceri and M. mediterraneum, and thus tightly clustered together (100\% BT value, Fig 4a). Similarly, the nifH gene sequence-based phylogenetic tree (Fig. 4b) also demonstrated the tight clustering (99\% BT value) of the new test strains with the M. ciceri and M. mediterraneum.

Taken together, we clearly demonstrated that the phylogeny derived from the symbiosis-related genes were not consistent with the phylogenetic tree constructed from the house-keeping genes, suggesting the different evolutionary history between chromosomal and symbiosis-related genes. Chickpea is confirmed as a non-promiscuous host, and thus can be nodulated by strains of several species of Mesorhizobium harboring nearly identical nodulation genes (Rivas et al. 2007; Laranjo et al. 2008). In agreement with this, our results indicated that the four genospecies that nodulate chickpea shared common NodA genes, suggesting recognition of only a few Nod genes by chickpea. This study has contributed to the knowledge that rhizobia with different chromosomal backgrounds may carry similar symbiosis genes, explaining how a restrictive host for nodulation, such as chickpea, is nodulated by several different Mesorhizobium species.

On analysis of results on symbiotic effectiveness, all tested strains were able to infect their host plant and fix atmospheric $\mathrm{N}$, leading to more plant shoot production and $\mathrm{N}$ uptake than in the uninoculated and N-free controls. The correlation analyses revealed positive and highly significant $(\mathrm{p}<0.001)$ associations of nodule number and nodule dry weight with shoot dry weight $(\mathrm{r}=0.49$ and 0.52, respectively). In earlier investigations in Ethiopia, Mnalku et al. (2009) and Argaw (2012) reported significant correlations of nodule number and dry weights with shoot dry biomass on faba bean inoculated with compatible rhizobia.

Howieson and Dilworth (2016) and Peoples et al. (2002) suggested that shoot dry matter is a good indicator of relative effectiveness of a rhizobial isolate. The relative dry matter accumulation of chickpea in relation to the $\mathrm{N}$-fertilized positive control showed that five (12\%) of our isolates were highly effective, while twenty-four (57\%), nine $(21.5 \%)$ and four $(9.5 \%)$ of them were considered effective, poorly effective or ineffective, respectively. This is in agreement with the findings of Jida and Assefa (2012) who reported that Ethiopian soils harbor symbiotically diverse chickpeanodulating rhizobia, hence indicating possibilities to select effective strains to improve $\mathrm{N}$ fixation and grain yield of the crop. Higher $\mathrm{N}$ accumulation in shoots of inoculated plants, as compared to 
uninoculated controls, suggests greater $\mathrm{N}$ fixation and is a useful parameter to select strains for commercial inoculant production (Wani et al. 2007; Rokhzadi and Toashih 2011). The highly effective strains identified in this study (CP08, CP41, CP97, CP105, and CP133) can be considered potentially elite strains for chickpea inoculant production. Earlier, four out of the five strains that the present manuscript highlights as highly effective were already tested on pot and field trials and the result indicated that the chickpea indigenous rhizobial strain $\mathrm{Cp} 41$ was superior to all the others for almost all parameters (Tena et al. 2016), thus can be promoted for large scale inoculant production.

\section{Conclusion}

The symbiotic, phenotypic and genotypic characterization of chickpea nodulating rhizobia isolated from different chickpea growing area of Ethiopia revealed a wide diversity. Indigenous rhizobial isolates were phenotypically characterized in order to assess their ability to tolerate abiotic stress conditions including salinity, $\mathrm{pH}$ and high temperature. A dendrogram constructed from physiological and biochemical data placed the test strains into four main clusters. The phylogenetic analyses based on $16 \mathrm{~S}$ rRNA gene sequences indicated that the rhizobial strains nodulating chickpea in Ethiopia were distributed under the genus Mesorhizobium. Furthermore, the phylogenetic trees of concatenated genes $(r e c A, a t p D, g \ln I I$ and $g y r B)$ generated from sequence alignments of the test strains and the described reference species, revealed four groups (designated as genospecies I - IV) supported with high bootstrap values. Strains in genospecies I, II, and III could be classified with M. ciceri, M. abyssinicae, and M. shonense, respectively, whereas genospecies IV might be an unnamed Mesorhizobium genospecies. Our result indicated that the four genospecies that nodulate chickpea share common symbiosis genes. Overall, our results corroborated earlier findings that Ethiopian soils harbor phylogenetically diverse Mesorhizobium species, justifying further explorative studies. Some indigenous rhizobial isolates showed significant performance on nodulation status and plant growth parameters on inoculated chickpea plants compared to the uninoculated control treatments. The observed difference in symbiotic effectiveness underscores the potential to select effective strains for use as inoculants and to improve the productivity of chickpea within the country. 


\section{Acknowledgement}

This work was funded by Canadian International Food Security Research Fund (CIFSRF). Our thanks extend to Hawassa University and University of Saskatchewan soil microbiology staff member and Dr. Sheleme Beyene for their technical expertise and support during the research period.

\section{Appendix A. Supplementary data}

Supplementary data associated with this manuscript are Table S1, S2 and Figure S1.

\section{References}

Abaidoo, R.C., George, T., Bohlol, B.B., and Singleton, P.W. 1990. Influence of elevation and applied nitrogen on rhizosphere colonization and competition for nodule occupancy by different rhizobial strains on field-grown soybean and common bean. Can. J. Microbiol. 36: 92-96.

Acinas, S.G., Marcelino, L.A., Klepac-Ceraj, V., and Polz, M.F. 2004. Divergence and redundancy of 16S rRNA sequences in genomes with multiple rrn operons. Journal of Bacteriology 186: 26292635.

Alexandre, A., Brigido, C., Laranjo, M., Rodrigues, S., and Oliveira, S. 2009. Survey of chickpea rhizobia diversity in Portugal reveals the predominance of species distinct from Mesorhizobium ciceri and Mesorhizobium mediterraneum. Microbial Ecology 58: 930-941.

Alikahani, H.A., Saleh-Rastin, N., and Antoun, H. 2006. Phosphate solubilization activity of rhizobia native to Iranian soils. Plant and Soil 287:35-41.

Amarger, N., Macheret, V., and Laguerre, G. 1997. Rhizobium gallicum spp. Nov. and Rhizobium spp. Nov. from Phaseolus vulgaris nodules. Int. J. Syst. Bacteriol 47:996-1006.

Argaw, A. 2012. Characterization of symbiotic effectiveness of rhizobia nodulating Faba bean (Vicia faba L.) isolated from central Ethiopia. Research Journal of Microbiology 7:280-296.

Aserse, A.A., Räsänen, L.A., Aseffa, F., Hailemariam, A., and Lindström, K. 2013. Diversity of sporadic symbionts and nonsymbioticendophytic bacteria isolated from nodules of woody, shrub, and food legumes in Ethiopia. Applied Microbiology and Biotechnology 97:10117-101134.

Aserse, A.A., Räsänen, L.A., Assefa, F., Hailemariam, A., and Lindström, K. 2012. Phylogeny and genetic diversity of native rhizobia nodulating common bean (Phaseolus vulgaris L.) in Ethiopia. Syst. Appl. Microbiol 35:120-131. 
Boom, R., Sol, C.J.A., Salimans, M.M.M., Jansen, C.L., Dillen, P.M.E.W.V., and Noordaa, J.V.D. 1990. Rapid and simple method for purification of nucleic acids. Journal of Clinical Microbiology 28:495-503.

Broughton, W.J., and Perret, X. 1999. Genealogy of legume-Rhizobium symbioses. Curr Opin Plant Biol 2:305-311.

Cadahia, E., Leyvar, A., and Ruiz-Argueso, T. 1986. Indigenous plasmids and cultural characteristic of rhizobia nodulating chickpeas (Cicer arietinum L.). Archive of Microbiology 146:239-244.

CSA, (Central Statistical Agency). 2013. Agricultural Sample Survey 2012/2013: Area and production of crops (Private Peasant holdings, Meher Season). Statistical Bulletin 532, Addis Ababa, Ethiopia.

Degefu, T., Wolde-Meskel, E., and Frostegård, Å. 2011. Multilocus sequence analyses reveal several unnamed Mesorhizobium genospecies nodulating Acacia species and Sesbania sesban trees in southern regions of Ethiopia. Syst. Appl. Microbiol 34:216-226.

Degefu, T., Wolde-Meskel, E., Liu, B., Cleenwerck, I., Willems, A., and Frostegård, Å. 2013. Mesorhizobium shonense sp. nov., Mesorhizobium hawassense sp.nov. and Mesorhizobium abyssinicae sp. nov. isolated from root nodules of different agroforestry legume trees growing in southern Ethiopia. Int. J. Syst. Evol. Microbiol63:1746-1753.

De Lajudie, P., Willems, A., Nick, G., Moreira, F., Molouba, F., Hoste, B., Torck, U., Neyra, M., Collins, M.D., Lindström, K., Dreyfus, B., and Gillis, M. 1998. Characterization of tropical tree rhizobia and description of Mesorhizobium plurifarium sp. nov. Int. J. Syst. Bacteriol 48:369382.

FAO. 2015. Food and Agriculture Organizations of the United Nations: Statistics Division. Available online: http://faostat.fao.org/site/567/default.aspx (accessed on 27 January 2016).

Farida, B., Géraldine, D., Abdelghani, B., Djellali, B., Said, B., and Gisèle, L. 2009. Retama species growing in different ecological-climatic areas of northeastern Algeria have a narrow range of rhizobia that form a novel phylogenetic clade within the Bradyrhizobium genus. Syst. Appl. Microbiol 32:245-255.

Gaunt, M.W., Turner, S.L., Rigottier-Gois, L., Lloyd-Macgilp, S.A., and Young, J.P.W. 2001. Phylogenies of atpD and recA support the small subunit rRNA-based classification of rhizobia. Int. J. Syst. Evol. Microbiol 51:2037-2048.

Gaur, Y.D., and Sen, A.N. 1979. Cross inoculation group specificity in Cicer-Rhizobium symbiosis, The New Phytologist 83:745-754. 
Hall, T.A. 2004. BioEdit: a user-friendly biological sequence alignment editor and analysis program for Windows 95/98/NT. Nucleic Acids SympSer 41:95-98.

Howieson, J.G., and Dilworth, M.J. 2016. Working with rhizobia. Australian Center for International Agricultural Research (ACIAR) Monograph No. 173: Canberra.

Jarvis, B.D.W., VanBerkum, P., Chen, W.X., Nour, S.M., Fernandez, M.P., Cleyet-Marel, J.C., and Gillis, M. 1997. Transfer of Rhizobium loti, Rhizobium huakuii, Rhizobium ciceri, Rhizobium mediterraneum, and Rhizobium tianshanense to Mesorhizobium gen. nov. Int. J. Syst. Bacteriol 47:895-898.

Jida, M., and Assefa, F. 2012. Phenotypic diversity and plant growth promoting characteristics of Mesorhizobium species isolated from chickpea (Cicer arietinum L.) growing areas of Ethiopia. African Journal of Biotechnology 11:7483-7493.

Keneni, G., Endashaw Bekele, E., Imtiaz, M., Getu, E., Dagne, K., and Assefa, F. 2011. Breeding chickpea (Cicer arietinum [Fabaceae]) for better seed quality inadvertently increased susceptibility to adzuki bean beetle (Callosobruchus chinensis [Coleoptera: Bruchidae]). International Journal of Tropical Insect Science. 32 (4): 249-261.

Kim, D.H., Kaashyap, M., Rathore, A., Das, R.R., Parupalli, S., Upadhyaya, H.D., Gopalakrishnan, S., Gaur, P.M., Singh, S., Kaur, J., Yasin, M., and Varshney, R.K. 2014. Phylogenetic diversity of Mesorhizobium in chickpea. J. Biosci 39:513-517.

Konstantinidis, K.T., Ramette, A., and Tiedje, J.M. 2006. Toward a more robust assessment of intraspecies diversity, using fewer genetic markers. Appl. Environ. Microbiol 72:7286-7293.

Kyei-Boahen, S., Slinkard, A.E., and Walley. F.L. 2002. Evaluations of rhizobial inoculation methods for chickpea. Agron. J. 94:851-859.

Laguerre, G., Nour, S.M., Macheret, V., Sanjuan, J., Drouin, P., and Amarger, N. 2001. Classification of rhizobia based on nodC and nifH gene analysis reveals a close phylogenetic relationship among Phaseolus vulgaris symbionts. Microbiology 147:981-993.

Laranjo, M., Alexandre, A., Rivas, R., Velázquez, E., Young, J.P.W., and Oliveira, S. 2008. Chickpea rhizobia symbiosis genes are highly conserved across multiple Mesorhizobium species. EMS Microbiol. Ecol. 66:391-400.

Laranjo, M., Machado, J., Young, J.P.W., and Oliveira, S. 2004. High diversity of chickpea Mesorhizobium species isolated in a Portuguese agricultural region. FEMS Microbial Ecology 48, 101-107. 
Laranjo, M., Young, J.P.W., and Oliveira, S. 2012. Multilocus sequence analysis reveals multiple symbiovars within Mesorhizobium Species. Syst. Appl. Microbiol35:359- 367.

Maâtallah, J., Berraho, E.B., Muñoz, S., Sanjuan, J., and Lluch, C. 2002. Phenotypic and molecular characterization of chickpea rhizobia isolated from different areas of Morocco. Journal of Applied Microbiology 93:531-540.

Martens, M., Dawyndt, P., Coopman, R., Gillis, M., De Vos, P., and Willems, A. 2008. Advantages of multilocus sequence analysis for taxonomic studies: a case study using 10 house-keeping genes in the genus Ensifer (including former Sinorhizobium). Int. J. Syst. Evol. Microbiol 58, 200-214.

Menna, P., Barcellos, F.G., and Hungria, M. 2009. Phylogeny and taxonomy of a diverse collection of Bradyrhizobium strains based on Multilocus Sequence Analysis of the 16S rRNA gene, ITS region and glnII, recA, atpD and dnaK genes. Int. J. Syst. Evol. Microbiol 59:2934-2950.

Mnalku, A., Gebrekidan, H., and Assefa, F. 2009. Symbiotic effectiveness and characterization of Rhizobium strains of faba bean (Vicia faba L.) collected from eastern and western Hararghe highlands of Ethiopia. Ethiopian Journal of Natural Resources 11:223-244.

Nour, S.M., Cleyet-Marel, J.C., Beck, D., Effoss, A., and Fernando, M.P. 1994a. Genotypic and phenotypic diversity of Rhizobium isolated from chickpea (Cicer arietinum L.). Can. J. Microbiol 40:345-354.

Nour, S.M., Cleyet-Marel, J.C., Normand, P., and Fernandez, M.P. 1995. Genomic heterogeneity of strains nodulating chickpea (Cicer arietinum L.) and description of Rhizobium mediterraneum sp. nov. Int. J. Syst. Bacteriol 45:640-648.

Nour, S.M., Fernandez, M.P., Normand, P., and Cleyet-Marel, J.C. 1994b. Rhizobium ciceri sp. nov., consisting of strains that nodulate chickpea (Cicer arietinum L.). International Journal of Systematic Bacteriology 44:511-522.

Peoples, M.B., Giller, K.E., Herridge, D.F., and Vessey, J.K. 2002. Limitations to biological nitrogen fixation as a renewable source of nitrogen for agriculture. In: Finan, T., O’Brian, M, Lagzell, M.R.,Vessey, D.N.,Newton, W., (Eds), Nitrogen Fixation Global Perspectives. ABI Publishing, New York, pp. 356-360.

Purcino, H.M.A., Festin, P.M., and Elkan, G.H. 2000. Identification of Effective Strains of Bradyrhizobium for Archispintoi.Trop. Agric., 77:226-231. 
Rai, R., Dash, P.K., Mohapatra, T., and Singh, A. 2012. Phenotypic and molecular characterization of indigenous rhizobia nodulating chickpea in India. Indian Journal of Experimental Biology $50: 340-350$.

Rivas, R., Laranjo, M., Mateos, P.F., Oliveira, S., Mart'1nez-Molina, E., and Vel'azquez, E. 2007. Strains of Mesorhizobium amorphae and Mesorhizobium tianshanense, carrying symbiotic genes of common chickpea endosymbiotic species, constitute a novel biovar (ciceri) capable of nodulating Cicer arietinum. Lett. Appl. Microbiol. 44:412-418.

Rivas, R., Martens, M., de Lajudie, P., and Willems, A. 2009. Multilocus sequence analysis of the genus Bradyrhizobium. Syst. Appl. Microbiol 32:101-110.

Rivas, R., Velázquez, E., Willems, A., Vizcaíno, N., Subba-Rao, N.S., Mateos, P.F., Gillis, M., Dazzo, F.B., and Martínez-Molina, E. 2002. A new species of Devosia that forms a unique nitrogen-fixing rootnodule symbiosis with the aquatic legume Neptunianatans (L.f.) Druce. Applied Environmental Microbiology 68:5217-5222.

Rokhzadi, A., and Toashih, V. 2011. Nutrient uptake and yield of chickpea (Cicer arietinum L.) inoculated with plant growth promoting Rhizobacteria. AJCS 5(1):44-48.

Romdhane, S.B., Trabelsi, M., Aouani, M.E., de Lajudie, P., and Ridha Mhamdi, R. 2009. The diversity of rhizobia nodulating chickpea (Cicer arietinum) under water deficiency as a source of more efficient inoculants. Soil Biology \& Biochemistry 41:2568-2572.

SAS, Institute., Inc. 2012. The SAS System for Windows. Release 9.3; SAS Institute, Inc.: Cary, NC, USA.

Sprent, J.I. 2007. Evolving ideas of legume evolution and diversity: a taxonomic perspective on the occurrence of nodulation. New Phytol. 174:11-25.

Stackebrandt, E., Frederiksen, W., Garrity, G.M., Grimont, P.A., Kämpfer, P., Maiden, M.C.J., Nesme, X., Rosselló-Mora, R., and Swings, J. 2002. Report of the ad hoc committee for the reevaluation of the species definition in bacteriology. Int. J. Syst. Evol. Microbiol 52:1043-1047.

Suneja, P., Dudeja, S.S., and Dahiya, P. 2016. Deciphering the phylogenetic relationships among rhizobia nodulating chickpea: A Review. Journal of Applied Biology and Biotechnology 4:6170.

Tamura, K., Stecher, G., Peterson, D., Filipski, A., and Kumar, S. 2013. MEGA6: Molecular Evolutionary Genetics Analysis Version 6.0. Molecular Biology and Evolution 30:2725-2729. 
Tena, W., Wolde-Meskel, E., and Walley, F. 2016. Response of chickpea (Cicer arietinum L.) to inoculation with native and exotic Mesorhizobium strains in Southern Ethiopia. Afr. J. Biotechnol. 15(35): 1920-1929.

Terefework, Z., Kaijalainen, S., and Lindström, K. 2001. AFLP fingerprinting as a tool to study the genetic diversity of Rhizobium galegae isolated from Galegaorientalis and Galegaofficinalis. Journal of Biotechnology 91:169-180.

Thompson, J.D., Higgins, D.G., and Gibson, T.J. 1994. CLUSTAL W: improving the sensitivity of progressive multiple sequence alignment through sequence weighting, position-specific gap penalties and weight matrix choice. Nucleic Acids Research 22:4673-4680.

vanBerkum, P., Leibold, J.M., and Eardly, B.D. 2006. Proposal for combining Bradyrhizobium spp. (Aeschynomene indica) with Blastobacter denitrificans and to transfer Blastobacter denitrificans (Hirsh and Muller, 1985) to the genus Bradyrhizobium as Bradyrhizobium denitrificans (comb. nov.). Syst. Appl. Microbiol 29:207-215.

Vandamme, P., Pot, B., Gillis, M., De Vos, P., Kersters, K., and Swings, J. 1996. Polyphasic taxonomy, a consensus approach to bacterial systematics. Microbiol. Rev. 60:407-438.

Vincent, J.M. 1970. A manual for the practical study of root nodule bacteria. Blackwell, Oxford.

Wang, E.T., van Berkum, P., Beyene, D., Sui, X.H., Dorado, O., Chen, W.X. and Martínez-Romero, E. 1998. Rhizobium huautlense sp. nov., a symbiont of Sesbania herbacea that has a close phylogenetic relationship with Rhizobium galegae. Int. J. Syst. Bacteriol. 48:687-699.

Wani, P.A., Khan, M.S., and Zaidi, A. 2007. Synergistic effects of the inoculation with nitrogenfixing and phosphate solubilizing rhizobacteria on the performance of field grown chickpea. J Plant Nutr Soil Sci 170(2):283-287.

Weisburg, W.G., Barns, S.M., Pelletier, D.A., and Lane, D.J. 1991. 16S ribosomal DNA amplification for phylogenetic study. Journal of Bacteriology 173:697-703.

Wolde-Meskel, E. 2007. Genetic diversity of rhizobia in Ethiopian soils: their potential to enhance biological $\mathrm{N}$ fixation (BNF) and soil fertility for sustainable agriculture. Ethiopian Journal of Biological Science 69:77-95.

Wolde-Meskel, E., Terefework, Z., Frostegård, Å., and Lindström, K. 2005. Genetic diversity and phylogeny of rhizobia isolated from agroforestry legume species in southern Ethiopia. Int. J. Syst. Evol. Microbiol 55:1439-1452.

Xie, J., Knight, J.D., and Leggett, M.E. 2009. Comparison of media used to evaluate Rhizobium leguminosarumbiovarviciae for phosphate solubilizing ability. Can. J. Microbiol 55:910-915. 
Yanggen, D., Kelly, V., Reardon, T., and Naseem, A. 1998. Incentives for fertilizer use in subSaharan Africa: A review of empirical evidence on fertilizer response and profitability", MSU International Development Working Paper No. 70, Department of Agricultural Economics, Michigan State University, East Lansing, USA, 1998.

Zahran, H.H. 1999. Rhizobium-legume symbiosis and nitrogen fixation under severe conditions and in an arid climate. Microbiol. Molecul. Biol. Rev. 63:968-989.

Zahran, H.H., Abdel-Fattah, M., Ahmad, M.S., and Zaki, A.Y. 2003. Polyphasic taxonomy of symbiotic rhizobia from wild leguminous plants growing in Egypt. Folia Microbiologica 48:510_ 520.

Zakhia, F., and De Lajudie, P. 2001. Taxonomy of rhizobia. Agronomie. 21:569-576.

Zhang, X., Harper, R., Karsisto, M., and Lindstrom, K. 1991. Diversity of rhizobium bacteria isolated from the root nodules of leguminous trees. Int. J. Syst. Bacteriol 41:104-113. 


\section{Table and Figure Legends}

Table 1. List of rhizobial strains isolated from root nodules of chickpea in Ethiopia and their phenotypic groupings and phylogenetic positions.

Table 2. The effect of inoculation of rhizobia nodulating chickpea on shoot dry weight per plant (SDWP), shoot nitrogen content per plant (SNCP), nodule number per plant (NNP), nodule dry weight per plant (NDWP) and the percent symbiotic effectiveness (SE\%) under control conditions using sand culture

Figure 1. Map of Ethiopia showing soil sampling sites

Figure 2. Neighbor-joining phylogenetic tree based on $16 S r R N A$ (a) and concatenated (atpD, glnII, rec $A$ and $g y r B$ ) (b) gene sequences showing the relationships among chickpea microsymbionts tested strains, and recognized species of the genus Mesorhizobium. The group (I - IV) generated on the concatenated gene-based phylogeny. Bootstrap values 70\% (based on 1000 replications) are shown at each node. Bars indicate the \% of estimated nucleotide substitutions per site. M: Mesorhizobium. R: Rhizobium

Figure 3. Neighbor-joining phylogenetic trees based on $r e c A(a), a t p D(b), g \ln I I(\mathrm{c})$ and $g y r B(d)$ gene sequences showing the relationships among the different chickpea microsymbionts and recognized species of the genus Mesorhizobium. Bootstrap values over 70\% (based on 1000 replications) are shown at each node. Bars indicate the $\%$ of estimated nucleotide substitutions per site. $M$ : Mesorhizobium.

Figure 4. Neighbor-joining phylogenetic trees based on sequences of symbiosis-related genes $\operatorname{nodA}$ (a) and $n i f H(b)$ genes, showing the relationships among the different chickpea isolates and recognized species of the genus Mesorhizobium. Bootstrap values over 70\% (based on 1000 replications) are shown at each node. Bars indicate the $\%$ of estimated substitutions expected number of changes per site. M: Mesorhizobium. 


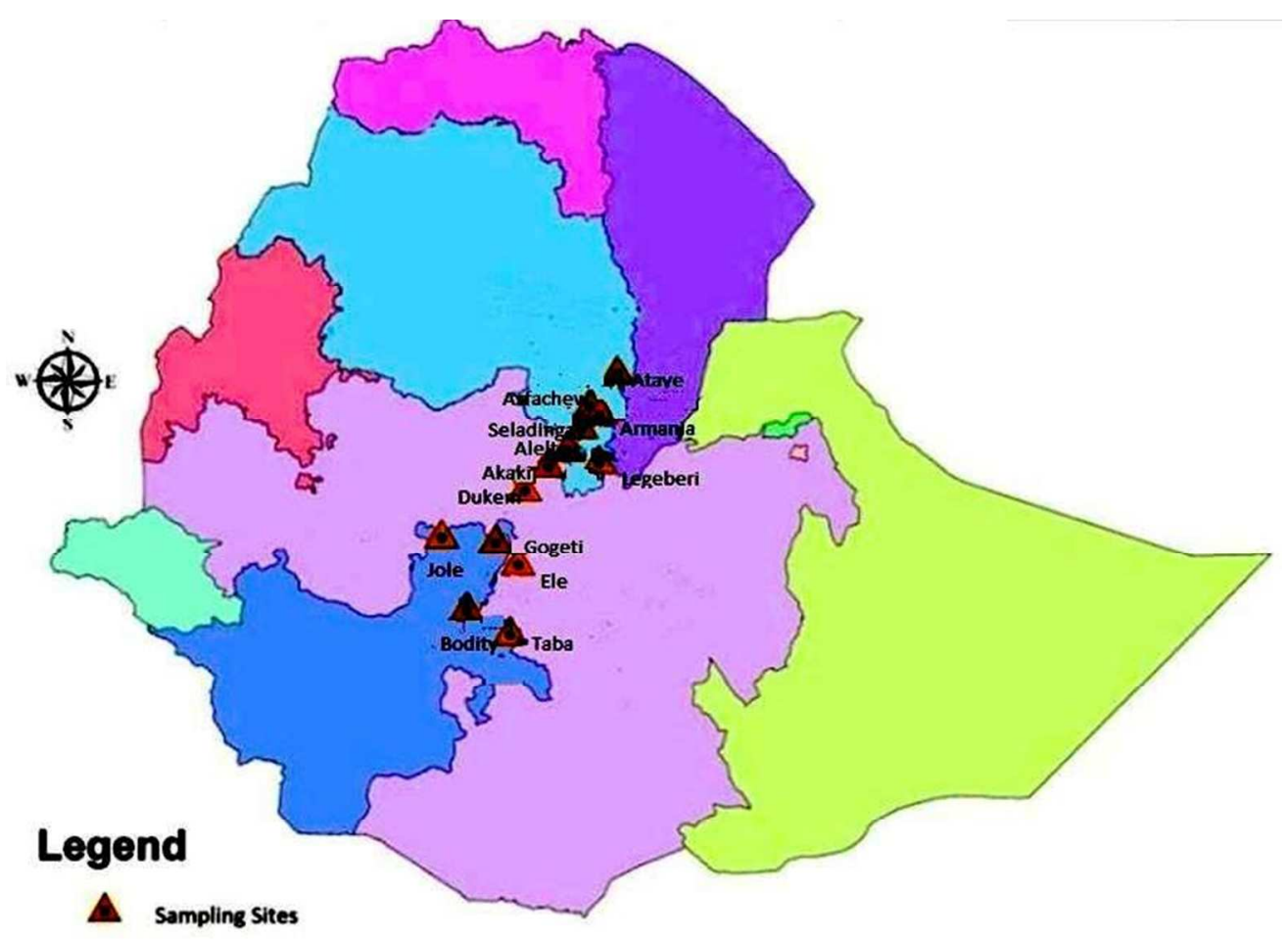

$234 \times 171 \mathrm{~mm}(96 \times 96$ DPI $)$ 

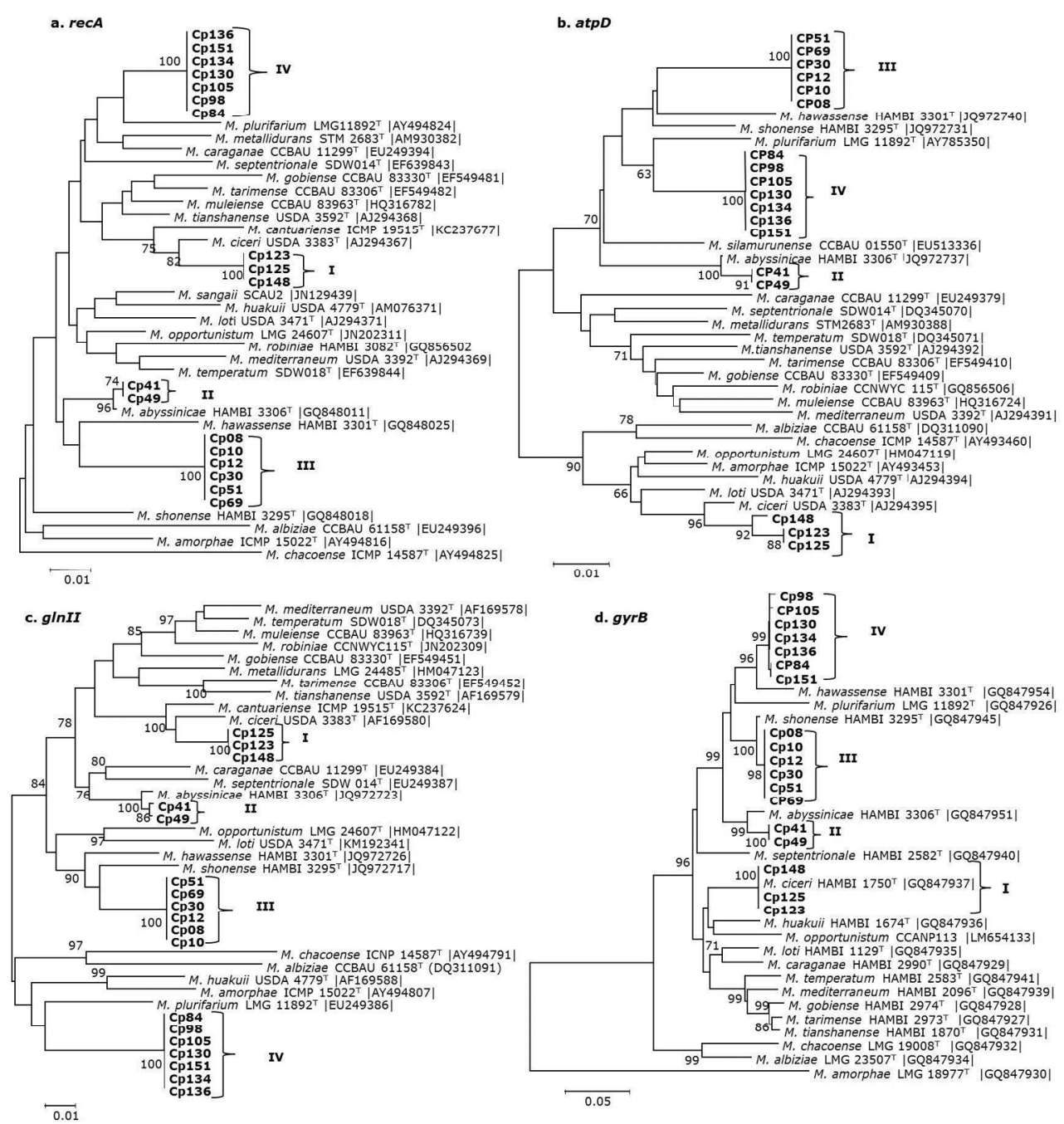

$573 \times 602 \mathrm{~mm}(78 \times 78$ DPI) 

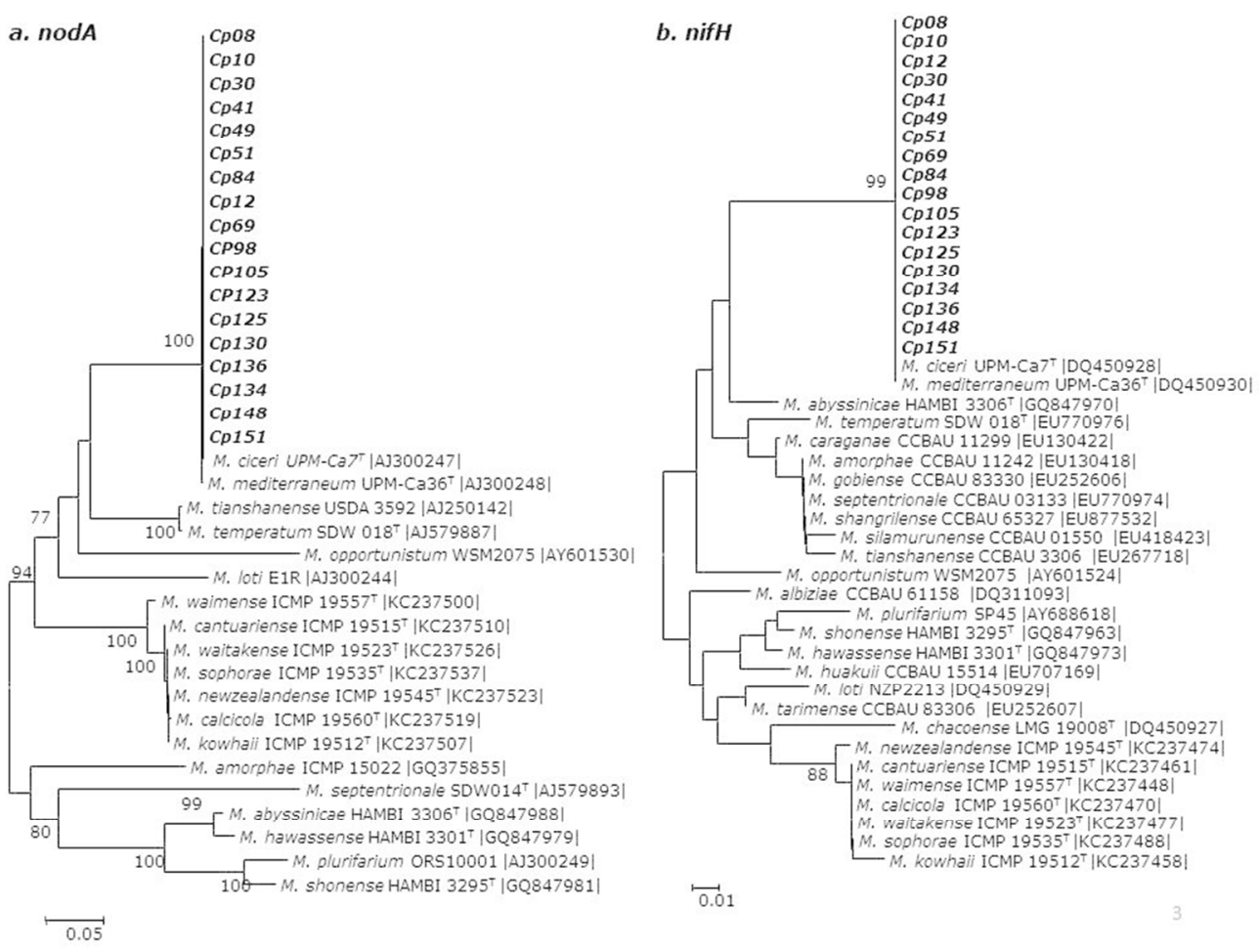

$254 \times 190 \mathrm{~mm}(96 \times 96 \mathrm{DPI})$ 


\begin{tabular}{|c|c|c|c|c|}
\hline \multirow[t]{2}{*}{ Strain } & \multirow{2}{*}{$\begin{array}{l}\text { Geographic } \\
\text { origin }\end{array}$} & \multirow{2}{*}{$\begin{array}{l}\text { Dendrogram } \\
\text { cluster }^{\mathrm{a}}\end{array}$} & \multicolumn{2}{|c|}{ Phylogenetic assignments } \\
\hline & & & Genospecies $^{b}$ & Assignments \\
\hline $\mathrm{CP} 1$ & Ele (SE) & I & - & - \\
\hline CP6 & Ele (SE) & I & - & - \\
\hline CP8 & Ele (SE) & I & III & M. shonense \\
\hline CP10 & Ele (SE) & I & III & M. shonense \\
\hline CP12 & Gogeti (SE) & I & III & M. shonense \\
\hline CP19 & Gogeti (SE) & I & - & - \\
\hline CP20 & Gogeti (SE) & I & - & - \\
\hline CP27 & Gogeti (SE) & I & - & - \\
\hline CP30 & Taba (SE) & I & III & M. shonense \\
\hline CP41 & Taba (SE) & I & II & M. abyssinica \\
\hline $\mathrm{CP} 44$ & Taba (SE) & I & - & - \\
\hline СР49 & Taba (SE) & I & II & M. abyssinica \\
\hline CP51 & Bodity (SE) & I & III & M. shonense \\
\hline CP61 & Bodity (SE) & III & - & - \\
\hline CP65 & Bodity (SE) & I & - & - \\
\hline СР69 & Jole (SE) & I & III & M. shonense \\
\hline CP74 & Jole (SE) & IV & - & - \\
\hline CP79 & Jole (SE) & I & - & - \\
\hline CP82 & Jole (SE) & I & - & - \\
\hline CP84 & Akaki (CE) & I & IV & Mesorhizobium sp. \\
\hline СР97 & Akaki (CE) & I & - & - \\
\hline СР98 & Akaki (CE) & II & IV & Mesorhizobium sp. \\
\hline СР99 & Akaki (CE) & IV & - & - \\
\hline CP100 & Dukem (CE) & IV & - & - \\
\hline CP105 & Dukem (CE) & I & IV & Mesorhizobium sp. \\
\hline CP109 & Dukem (CE) & I & - & - \\
\hline CP122 & Seladingay (CE) & I & - & - \\
\hline CP123 & Seladingay (CE) & I & I & M. ciceri \\
\hline CP125 & Seladingay (CE) & II & I & M. ciceri \\
\hline CP126 & Ataye (CE) & III & - & - \\
\hline CP130 & Ataye (CE) & III & IV & Mesorhizobium sp. \\
\hline CP132 & Ataye (CE) & I & - & - \\
\hline CP133 & Asfachew (CE) & I & - & - \\
\hline CP134 & Asfachew (CE) & I & IV & Mesorhizobium sp. \\
\hline CP135 & Asfachew (CE) & I & - & - \\
\hline CP136 & Armania (CE) & II & IV & Mesorhizobium sp. \\
\hline CP139 & Armania (CE) & I & - & - \\
\hline CP140 & Armania (CE) & I & - & - \\
\hline CP143 & Legeberi (CE) & III & - & - \\
\hline CP148 & Legeberi (CE) & I & I & M. ciceri \\
\hline CP150 & Aleltu (CE) & III & - & - \\
\hline CP151 & Aleltu (CE) & III & IV & Mesorhizobium sp. \\
\hline
\end{tabular}

SE, South Ethiopia; and CE, Central Ethiopia; M, Mesorhizobium; ${ }^{\mathrm{a}}$ Dendrogram highlighting the phenotypic similarities among rhizobial strains; ${ }^{\mathrm{b}}$ Genospecies defined based on phylogenetic tree constructed from the concatenated genes sequences (recA, atpD, glnII, and gyrB) tree. 


\begin{tabular}{|c|c|c|c|c|c|}
\hline Isolate Code & SDWP $^{\mathrm{a}}(\mathrm{g})$ & SE & $\mathrm{SNCP}^{\mathrm{a}}(\mathrm{mg})$ & $\mathbf{N N P}^{\mathrm{a}}$ & NDWP $^{\mathbf{a}}(\mathbf{m g})$ \\
\hline $\mathrm{CP} 1$ & $0.42 \pm 0.08^{\mathrm{H}-\mathrm{L}}$ & 43 & $11.4 \pm 2.9^{\mathrm{P}-\mathrm{U}}$ & $18.3 \pm 2.0^{\mathrm{N}}$ & $65.0 \pm 9.5^{\mathrm{J}-\mathrm{O}}$ \\
\hline CP6 & $0.54 \pm 0.09^{\mathrm{D}-\mathrm{L}}$ & 54 & $16.2 \pm 3.3^{\mathrm{L}-\mathrm{T}}$ & $46.0 \pm 8.2^{\mathrm{A}-\mathrm{G}}$ & $84.3 \pm 20.2^{\mathrm{F}-\mathrm{O}}$ \\
\hline CP8 & $0.81 \pm 0.07^{\mathrm{A}-\mathrm{C}}$ & 82 & $32.2 \pm 2.0^{\mathrm{C}-\mathrm{F}}$ & $26.0 \pm 3.0^{\mathrm{L}-\mathrm{M}}$ & $187.0 \pm 58.0^{\mathrm{AB}}$ \\
\hline CP10 & $0.43 \pm 0.04^{\mathrm{H}-\mathrm{L}}$ & 43 & $11.8 \pm 1.5^{\mathrm{P}-\mathrm{U}}$ & $17.3 \pm 4.3^{\mathrm{N}}$ & $68.3 \pm 7.9^{\mathrm{I}-\mathrm{O}}$ \\
\hline CP12 & $0.46 \pm 0.08^{\mathrm{G}-\mathrm{L}}$ & 46 & $13.0 \pm 3.1^{\mathrm{P}-\mathrm{U}}$ & $27.7 \pm 6.7^{\mathrm{E}-\mathrm{M}}$ & $80.7 \pm 5.3^{\mathrm{H}-\mathrm{O}}$ \\
\hline CP19 & $0.56 \pm 0.16^{\mathrm{C}-\mathrm{K}}$ & 56 & $16.9 \pm 5.1^{\mathrm{L}-\mathrm{S}}$ & $28.3 \pm 2.5^{\mathrm{I}-\mathrm{N}}$ & $110.0 \pm 8.9^{\mathrm{D}-\mathrm{K}}$ \\
\hline $\mathrm{CP} 20$ & $0.34 \pm 0.05^{\mathrm{K}-\mathrm{L}}$ & 34 & $9.7 \pm 1.4^{\mathrm{R}-\mathrm{U}}$ & $20.0 \pm 3.3^{\mathrm{MN}}$ & $57.7 \pm 18.7^{\mathrm{K}-\mathrm{O}}$ \\
\hline $\mathrm{CP} 27$ & $0.51 \pm 0.08^{\mathrm{E}-\mathrm{J}}$ & 51 & $14.9 \pm 1.5^{\mathrm{P}-\mathrm{U}}$ & $28.0 \pm 9.8^{\mathrm{I}-\mathrm{M}}$ & $97.0 \pm 12.1^{\mathrm{F}-\mathrm{N}}$ \\
\hline CP30 & $0.44 \pm 0.02^{\mathrm{H}-\mathrm{L}}$ & 44 & $12.2 \pm 1.7^{\mathrm{P}-\mathrm{U}}$ & $30.0 \pm 3.8^{\mathrm{E}-\mathrm{L}}$ & $101.3 \pm 1.5^{\mathrm{E}-\mathrm{N}}$ \\
\hline $\mathrm{CP} 41$ & $0.98 \pm 0.28^{\mathrm{A}}$ & 99 & $41.8 \pm 10.2^{\mathrm{AB}}$ & $59.7 \pm 15.2^{\mathrm{A}}$ & $207.7 \pm 36.2^{\mathrm{A}}$ \\
\hline $\mathrm{CP} 44$ & $0.57 \pm 0.17^{\mathrm{B}-\mathrm{K}}$ & 58 & $18.4 \pm 6.7^{\mathrm{K}-\mathrm{R}}$ & $30.7 \pm 7.1^{\mathrm{F}-\mathrm{N}}$ & $111.3 \pm 8.6^{\mathrm{D}-\mathrm{K}}$ \\
\hline CP49 & $0.72 \pm 0.15^{\mathrm{B}-\mathrm{F}}$ & 72 & $26.4 \pm 5.5^{\mathrm{D}-\mathrm{J}}$ & $26.7 \pm 8.6^{\mathrm{I}-\mathrm{N}}$ & $153.3 \pm 51.2^{\mathrm{B}-\mathrm{E}}$ \\
\hline CP51 & $0.46 \pm 0.03^{\mathrm{F}-\mathrm{L}}$ & 46 & $13.4 \pm 1.8^{\mathrm{O}-\mathrm{U}}$ & $40.0 \pm 5.8^{\mathrm{C}-\mathrm{L}}$ & $106.7 \pm 10.6^{\mathrm{F}-\mathrm{L}}$ \\
\hline CP61 & $0.63 \pm 0.04^{\mathrm{B}-\mathrm{I}}$ & 64 & $22.5 \pm 1.8^{\mathrm{H}-\mathrm{N}}$ & $29.3 \pm 4.8^{\mathrm{G}-\mathrm{L}}$ & $143.3 \pm 47.0^{\mathrm{B}-\mathrm{F}}$ \\
\hline CP65 & $0.33 \pm 0.02^{\mathrm{KL}}$ & 33 & $7.8 \pm 0.9^{\mathrm{TU}}$ & $42.7 \pm 3.9^{\mathrm{B}-\mathrm{J}}$ & $45.7 \pm 9.1^{\mathrm{NO}}$ \\
\hline CP69 & $0.36 \pm 0.09^{\mathrm{J}-\mathrm{K}}$ & 36 & $9.1 \pm 1.8^{\mathrm{S}-\mathrm{U}}$ & $44.7 \pm 3.5^{\mathrm{A}-\mathrm{H}}$ & $49.0 \pm 7.6^{\mathrm{MO}}$ \\
\hline CP74 & $0.35 \pm 0.04^{\mathrm{J}-\mathrm{K}}$ & 36 & $8.7 \pm 1.4^{\mathrm{S}-\mathrm{U}}$ & $17.0 \pm 3.9^{\mathrm{N}}$ & $52.3 \pm 5.5^{\mathrm{L}-\mathrm{O}}$ \\
\hline CP79 & $0.62 \pm 0.14^{\mathrm{B}-\mathrm{I}}$ & 63 & $22.0 \pm 6.1^{\mathrm{H}-\mathrm{O}}$ & $29.7 \pm 8.6^{\mathrm{H}-\mathrm{N}}$ & $135.7 \pm 34.2^{\mathrm{B}-\mathrm{H}}$ \\
\hline CP82 & $0.52 \pm 0.04^{\mathrm{E}-\mathrm{L}}$ & 53 & $15.6 \pm 2.2^{\mathrm{L}-\mathrm{U}}$ & $47.3 \pm 8.2^{\mathrm{A}-\mathrm{D}}$ & $116.3 \pm 10.3^{\mathrm{C}-\mathrm{J}}$ \\
\hline CP84 & $0.33 \pm 0.06^{\mathrm{K}-\mathrm{L}}$ & 33 & $10.8 \pm 3.5^{\mathrm{Q}-\mathrm{U}}$ & $18.7 \pm 1.1^{\mathrm{N}}$ & $70.0 \pm 6.9^{\mathrm{I}-\mathrm{O}}$ \\
\hline CP97 & $0.83 \pm 0.08^{\mathrm{AB}}$ & 84 & $12.2 \pm 3.7^{\mathrm{P}-\mathrm{U}}$ & $34.7 \pm 5.4^{\mathrm{D}-\mathrm{L}}$ & $103.7 \pm 30.1^{\mathrm{E}-\mathrm{M}}$ \\
\hline CP98 & $0.56 \pm 0.10^{\mathrm{C}-\mathrm{K}}$ & 57 & $17.3 \pm 3.6^{\mathrm{K}-\mathrm{T}}$ & $42.3 \pm 9.0^{\mathrm{B}-\mathrm{K}}$ & $142.3 \pm 39.8^{\mathrm{B}-\mathrm{F}}$ \\
\hline CP99 & $0.44 \pm 0.10^{\mathrm{H}-\mathrm{L}}$ & 44 & $33.2 \pm 2.4^{\mathrm{DC}}$ & $31.3 \pm 14.6^{\mathrm{D}-\mathrm{N}}$ & $63.0 \pm 23.9^{\mathrm{J}-\mathrm{O}}$ \\
\hline CP100 & $0.56 \pm 0.17^{\mathrm{C}-\mathrm{K}}$ & 57 & $17.2 \pm 5.8^{\mathrm{K}-\mathrm{T}}$ & $43.3 \pm 9.2^{\mathrm{B}-\mathrm{I}}$ & $168.3 \pm 47.0^{\mathrm{A}-\mathrm{C}}$ \\
\hline CP105 & $0.81 \pm 0.09^{\mathrm{A}-\mathrm{C}}$ & 82 & $32.3 \pm 5.2^{\mathrm{C}-\mathrm{E}}$ & $47.0 \pm 4.6^{\mathrm{A}-\mathrm{F}}$ & $163.3 \pm 16.2^{\mathrm{A}-\mathrm{D}}$ \\
\hline CP109 & $0.33 \pm 0.02^{\mathrm{KL}}$ & 33 & $18.0 \pm 1.6^{\mathrm{J}-\mathrm{R}}$ & $34.6 \pm 4.7^{\mathrm{D}-\mathrm{L}}$ & $48.9 \pm 8.1^{\mathrm{MO}}$ \\
\hline CP122 & $0.54 \pm 0.08^{\mathrm{D}-\mathrm{L}}$ & 54 & $19.5 \pm 1.5^{\mathrm{I}-\mathrm{Q}}$ & $43.3 \pm 7.2^{\mathrm{B}-\mathrm{I}}$ & $67.3 \pm 26.9^{\mathrm{I}-\mathrm{O}}$ \\
\hline CP123 & $0.57 \pm 0.03^{\mathrm{B}-\mathrm{K}}$ & 58 & $27.0 \pm 3.7^{\mathrm{C}-\mathrm{I}}$ & $43.0 \pm 5.2^{\mathrm{B}-\mathrm{I}}$ & $94.4 \pm 26.3^{\mathrm{F}-\mathrm{O}}$ \\
\hline CP125 & $0.59 \pm 0.07^{\mathrm{B}-\mathrm{J}}$ & 60 & $29.7 \pm 1.2^{\mathrm{C}-\mathrm{H}}$ & $42.7 \pm 8.4^{\mathrm{B}-\mathrm{J}}$ & $86.7 \pm 6.2^{\mathrm{G}-\mathrm{O}}$ \\
\hline CP126 & $0.73 \pm 0.10^{\mathrm{B}-\mathrm{E}}$ & 74 & $23.7 \pm 9.9^{\mathrm{H}-\mathrm{M}}$ & $51.3 \pm 9.0^{\mathrm{A}-\mathrm{C}}$ & $61.9 \pm 17.1^{\mathrm{JK}}$ \\
\hline CP130 & $0.79 \pm 0.03^{\mathrm{A}-\mathrm{D}}$ & 79 & $31.2 \pm 3.8^{\mathrm{C}-\mathrm{G}}$ & $58.3 \pm 15.4^{\mathrm{AB}}$ & $95.5 \pm 41.5^{\mathrm{F}-\mathrm{O}}$ \\
\hline CP132 & $0.66 \pm 0.30^{\mathrm{B}-\mathrm{H}}$ & 66 & $25.7 \pm 6.7^{\mathrm{D}-\mathrm{K}}$ & $46.3 \pm 7.5^{\mathrm{A}-\mathrm{F}}$ & $121.0 \pm 21.9^{\mathrm{C}-\mathrm{I}}$ \\
\hline CP133 & $0.80 \pm 0.11^{\mathrm{A}-\mathrm{C}}$ & 81 & $29.5 \pm 4.3^{\mathrm{C}-\mathrm{H}}$ & $57.7 \pm 8.6^{\mathrm{AB}}$ & $179.8 \pm 42.0^{\mathrm{AB}}$ \\
\hline CP134 & $0.70 \pm 0.17^{\mathrm{B}-\mathrm{G}}$ & 71 & $22.4 \pm 8.5^{\mathrm{H}-\mathrm{N}}$ & $51.7 \pm 9.5^{\mathrm{A}-\mathrm{C}}$ & $117.2 \pm 16.2^{\mathrm{C}-\mathrm{J}}$ \\
\hline CP135 & $0.79 \pm 0.08^{\mathrm{A}-\mathrm{D}}$ & 79 & $22.8 \pm 4.0^{\mathrm{H}-\mathrm{N}}$ & $37.7 \pm 5.5^{\mathrm{C}-\mathrm{L}}$ & $56.6 \pm 22.9^{\mathrm{K}-\mathrm{O}}$ \\
\hline CP136 & $0.63 \pm 0.24^{\mathrm{B}-\mathrm{I}}$ & 64 & $20.2 \pm 5.7^{\mathrm{I}-\mathrm{P}}$ & $47.0 \pm 12.5^{\mathrm{A}-\mathrm{E}}$ & $67.3 \pm 26.9^{\mathrm{I}-\mathrm{O}}$ \\
\hline CP139 & $0.64 \pm 0.11^{\mathrm{B}-\mathrm{H}}$ & 65 & $27.2 \pm 7.8^{\mathrm{C}-\mathrm{H}}$ & $47.3 \pm 11.1^{\mathrm{A}-\mathrm{D}}$ & $138.6 \pm 44.2^{\mathrm{B}-\mathrm{G}}$ \\
\hline CP140 & $0.60 \pm 0.19^{\mathrm{B}-\mathrm{J}}$ & 60 & $18.7 \pm 1.5^{\mathrm{I}-\mathrm{Q}}$ & $26.3 \pm 1.6^{\mathrm{K}-\mathrm{N}}$ & $40.5 \pm 18.4^{\mathrm{O}}$ \\
\hline CP143 & $0.73 \pm 0.18^{\mathrm{B}-\mathrm{E}}$ & 74 & $15.2 \pm 2.7^{\mathrm{M}-\mathrm{U}}$ & $42.3 \pm 6.6^{\mathrm{B}-\mathrm{K}}$ & $69.7 \pm 19.9^{\mathrm{I}-\mathrm{O}}$ \\
\hline CP148 & $0.58 \pm 0.01^{\mathrm{B}-\mathrm{K}}$ & 59 & $24.2 \pm 2.7^{\mathrm{P}-\mathrm{U}}$ & $32.7 \pm 4.7^{\mathrm{E}-\mathrm{N}}$ & $52.7 \pm 15.8^{\mathrm{L}-\mathrm{O}}$ \\
\hline CP150 & $0.48 \pm 0.09^{\mathrm{E}-\mathrm{L}}$ & 49 & $35.2 \pm 5.2^{\mathrm{BC}}$ & $35.0 \pm 0.5^{\mathrm{D}-\mathrm{M}}$ & $52.8 \pm 11.7^{\mathrm{L}-\mathrm{O}}$ \\
\hline CP151 & $0.67 \pm 0.06^{\mathrm{B}-\mathrm{H}}$ & 67 & $11.8 \pm 2.2^{\mathrm{P}-\mathrm{U}}$ & $60.3 \pm 7.6^{\mathrm{A}}$ & $93.0 \pm 11.5^{\mathrm{F}-\mathrm{O}}$ \\
\hline
\end{tabular}




\begin{tabular}{llccc}
\hline Control $^{\mathbf{b}}$ & $0.30 \pm 0.02^{\mathrm{L}}$ & 30 & $6.9 \pm 0.5^{\mathrm{U}}$ \\
$\mathrm{N}^{\mathbf{c}}+$ & $0.99 \pm 0.12^{\mathrm{A}}$ & 100 & $42.8 \pm 3.9^{\mathrm{A}}$ & \\
$\mathrm{CV}(\%)^{\mathrm{d}}$ & 21.6 & 21.6 & 21.4 & 27.7 \\
Significant & $* * *$ & $* * *$ & $* * *$ & $* * *$ \\
\hline${ }^{\mathbf{a}}$ Values are mean \pm SE of three replicates, mean values followed by the same letters in each \\
column and treatment showed no significant difference by DMRT $(\mathrm{p}=0.05){ }^{\mathbf{b}}$ Control: without \\
chemical and biological fertilizers. ${ }^{\mathbf{c}} \mathrm{N}$ : with optimum amount of nitrogen fertilizer. ${ }^{\mathbf{d}} \mathrm{CV}(\%)$ : \\
percent coefficient of variability. ${ }^{\mathrm{e}}$ Significant: probability level. $* * *$ showed significant \\
difference at 0.001 probability levels.
\end{tabular}


Genetic and phenotypic diversity of rhizobia nodulating Chickpea (Cicer arietinum L.) in soils from southern and central Ethiopia

Wondwosen Tena $^{{ }^{*}}$, Endalkachew Wolde-Meskel ${ }^{2}$, Tulu Degefu ${ }^{3}$, and Fran Walley ${ }^{4}$

${ }^{1}$ Debre Berhan University, Department of Plant Science, P.O. Box 445, Debre Berhan, Ethiopia;

${ }^{2}$ International Livestock Research Institute, P.O. Box 5689, Addis Ababa, Ethiopia;

${ }^{3}$ Hawassa University, Department of Biology, P.O.Box 05;

${ }^{4}$ Department of Soil Science, College of Agriculture and Bioresources, University of Saskatchewan, 51 Campus Drive, Saskatoon, Canada, S7N 5A8.

*Author to whom correspondence should be addressed; E-Mail: wondtena@gmail.com; Tel.: +251911184535. 
Table S1. Differentiating phenotypic traits of 42 chickpea isolates

\begin{tabular}{|c|c|c|c|c|c|c|c|c|c|}
\hline \multicolumn{6}{|c|}{ Cluster $^{\mathrm{a}}$} & \multicolumn{4}{|c|}{ Cluster } \\
\hline Characteristic & $\begin{array}{l}I \\
\left(n^{b}=30\right)\end{array}$ & $\begin{array}{l}\text { II } \\
(n=3)\end{array}$ & $\begin{array}{l}\text { III } \\
(n=6)\end{array}$ & $\begin{array}{l}\text { IV } \\
(n=3)\end{array}$ & Characteristic & $\begin{array}{l}I \\
(n=30)\end{array}$ & $\begin{array}{l}\text { II } \\
(n=3)\end{array}$ & $\begin{array}{l}\text { III } \\
(n=6)\end{array}$ & $\begin{array}{l}\text { IV } \\
(n=3)\end{array}$ \\
\hline \multicolumn{5}{|c|}{ Temperature tolerance } & \multicolumn{5}{|c|}{ Carbohydrate Utilization ${ }^{c}$} \\
\hline $5^{\circ} \mathrm{C}$ & 0 & 0 & 0 & 0 & Dextrin & 26 & 2 & 5 & 2 \\
\hline $15^{\circ} \mathrm{C}$ & 12 & 0 & 4 & 0 & Maltose & 19 & 1 & 4 & 3 \\
\hline $20-30^{\circ} \mathrm{C}$ & 30 & 3 & 6 & 3 & Xylose & 19 & 3 & 6 & 3 \\
\hline $35^{\circ} \mathrm{C}$ & 25 & 2 & 6 & 3 & Rhamnose & 21 & 3 & 6 & 3 \\
\hline $40^{\circ} \mathrm{C}$ & 5 & 0 & 1 & 0 & Raffinose & 10 & 0 & 5 & 2 \\
\hline \multicolumn{5}{|l|}{$\mathrm{NaCl}$ tolerance } & Soribitol & 27 & 3 & 6 & 3 \\
\hline $1 \%$ & 30 & 3 & 6 & 3 & Dulicitol & 27 & 3 & 6 & 3 \\
\hline $2 \%$ & 25 & 3 & 6 & 2 & Arabinose & 15 & 2 & 4 & 3 \\
\hline $3 \%$ & 0 & 0 & 3 & 1 & Malonic Acid & 6 & 0 & 1 & 1 \\
\hline $4 \%$ & 0 & 0 & 2 & 0 & Xylitol & 9 & 1 & 5 & 2 \\
\hline $5 \%$ & 0 & 0 & 2 & 0 & Myo-inositol & 28 & 2 & 6 & 3 \\
\hline \multicolumn{5}{|l|}{ pH tolerance } & Glycine & 8 & 1 & 2 & 2 \\
\hline 4 & 1 & 2 & 1 & 0 & & & & & \\
\hline 4.5 & 7 & 2 & 4 & 0 & \multicolumn{5}{|c|}{ Phosphate solubilization } \\
\hline 5 & 13 & 3 & 6 & 0 & Phosphate & 12 & 0 & 4 & 2 \\
\hline 5.5 & 16 & 3 & 6 & 3 & \multicolumn{5}{|c|}{ Antibiotics Resistance in $\mu \mathrm{g} \mathrm{ml}^{-1 \mathrm{c}}$} \\
\hline 8 & 30 & 3 & 6 & 3 & Chloramphenicol (5) & 29 & 3 & 6 & 3 \\
\hline 8.5 & 30 & 3 & 6 & 3 & Chloramphenicol (15) & 14 & 3 & 6 & 3 \\
\hline 9 & 26 & 1 & 3 & 1 & Kanamycin (15) & 19 & 2 & 4 & 0 \\
\hline 9.5 & 19 & 1 & 3 & 0 & Trimethoprim (200) & 24 & 3 & 2 & 3 \\
\hline 10 & 17 & 0 & 1 & 0 & Novobiocin (5) & 9 & 1 & 6 & 3 \\
\hline \multicolumn{5}{|c|}{ Nitrogen utilization $^{\mathrm{c}}$} & \multicolumn{5}{|c|}{ Heavy Metal Resistance in $\mu \mathrm{g} \mathrm{ml}^{-1 \mathrm{c}}$} \\
\hline Serine & 6 & 2 & 3 & 3 & $\operatorname{Mn}(500)$ & 4 & 1 & 3 & 3 \\
\hline Thymidine & 27 & 3 & 6 & 3 & $\mathrm{Al}(500)$ & 7 & 3 & 6 & 1 \\
\hline Phenylalanine & 29 & 3 & 6 & 3 & $\mathrm{~Pb}(500)$ & 7 & 1 & 1 & 3 \\
\hline Isoleucine & 27 & 2 & 6 & 3 & Co (100) & 10 & 1 & 5 & 3 \\
\hline Aspartic Acid & 28 & 2 & 6 & 3 & $\mathrm{Cu}(100)$ & 2 & 1 & 1 & 0 \\
\hline Pyroglutamic Acid & 29 & 3 & 6 & 3 & & & & & \\
\hline Proline & 27 & 2 & 6 & 3 & & & & & \\
\hline Arginine & 20 & 2 & 6 & 3 & & & & & \\
\hline
\end{tabular}

${ }^{a}$ Clusters I, II, III and IV are as defined in Fig. 3. ${ }^{b}$ total number of isolates per cluster and the column numbers are those of the isolates giving a positive reaction. ${ }^{\mathrm{c}}$ substrates utilized or not utilized by all strains were omitted from the table. 
Table S2. Physiological and biochemical individual strain data.

Table S2.1. Physiological characteristics of the chickpea isolates

\begin{tabular}{|c|c|c|c|c|c|c|c|c|c|c|c|c|c|c|c|c|c|c|c|c|}
\hline \multirow{2}{*}{$\begin{array}{l}0 \\
\frac{0}{0} \\
0 \\
0 \\
\frac{\Xi}{0} \\
0 \\
0\end{array}$} & \multicolumn{6}{|c|}{ Temperature } & \multicolumn{5}{|c|}{ Salt } & \multicolumn{9}{|c|}{$\mathrm{pH}$} \\
\hline & $\underset{\wp}{\bigcup}$ & 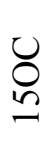 & 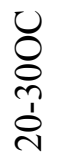 & $\begin{array}{l}\circlearrowright \\
\text { ๖ } \\
\text { n }\end{array}$ & ঠ̧ & $\begin{array}{l}\circlearrowright \\
\wp \\
\wp\end{array}$ & $\begin{array}{l}\bar{U} \\
Z\end{array}$ & $\begin{array}{l}\bar{U} \\
Z \\
\sim \\
\sim\end{array}$ & $\begin{array}{l}\bar{\Xi} \\
\bar{Z}\end{array}$ & $\begin{array}{l}\bar{\Xi} \\
Z \\
\forall\end{array}$ & $\begin{array}{l}\bar{U} \\
\text { Z } \\
n\end{array}$ & $\begin{array}{l}\frac{T}{2} \\
0 \\
0 \\
\dot{0}\end{array}$ & $\begin{array}{l}\frac{\pi}{n} \\
\stackrel{n}{7} \\
\forall\end{array}$ & $\begin{array}{l}\frac{\pi}{2} \\
\stackrel{2}{\circ}\end{array}$ & $\begin{array}{l}\frac{\pi}{n} \\
\text { n } \\
\text { n }\end{array}$ & $\underset{\infty}{\stackrel{\pi}{2}}$ & $\begin{array}{l}\frac{\pi}{2} \\
n \\
\infty\end{array}$ & $\begin{array}{l}\frac{T}{2} \\
0 \\
0\end{array}$ & $\begin{array}{l}\frac{7}{2} \\
\text { nุ } \\
\text { a }\end{array}$ & $\begin{array}{l}T \\
0 \\
0\end{array}$ \\
\hline CP01 & - & - & + & + & - & - & + & + & - & - & - & - & - & - & - & + & + & + & + & + \\
\hline CP06 & - & - & + & - & - & - & + & - & - & - & - & - & - & - & + & + & + & - & - & - \\
\hline CP08 & - & - & + & - & - & - & + & + & - & - & - & - & - & - & - & + & + & - & - & - \\
\hline CP10 & - & - & + & + & - & - & + & + & - & - & - & - & - & - & - & + & + & - & - & - \\
\hline CP12 & - & - & + & + & - & - & + & + & - & - & - & - & - & - & + & + & + & - & - & - \\
\hline CP19 & - & - & + & - & - & - & + & + & - & - & - & - & - & - & - & + & + & - & - & - \\
\hline CP20 & - & - & + & + & - & - & + & - & - & - & - & - & - & - & - & + & + & - & - & - \\
\hline CP27 & - & - & + & + & - & - & + & + & - & - & - & - & - & - & - & + & + & + & + & - \\
\hline CP30 & - & - & + & - & - & - & + & + & - & - & - & - & - & + & + & + & + & + & + & - \\
\hline CP41 & - & - & + & + & - & - & + & - & - & - & - & - & - & - & - & + & + & - & - & - \\
\hline CP44 & - & - & + & - & - & - & + & - & - & - & - & - & - & - & + & + & + & - & - & - \\
\hline CP49 & - & - & + & - & - & - & + & + & - & - & - & - & - & - & + & + & + & - & - & - \\
\hline CP51 & - & + & + & + & - & - & + & + & - & - & - & - & - & - & + & + & + & + & + & + \\
\hline CP61 & - & + & + & + & - & - & + & + & - & - & - & - & + & + & + & + & + & - & - & - \\
\hline CP65 & - & + & + & + & - & - & + & + & - & - & - & - & - & - & - & + & + & + & + & + \\
\hline CP69 & - & + & + & + & - & - & + & + & - & - & - & - & - & - & - & + & + & - & - & - \\
\hline CP74 & - & + & + & + & - & - & + & + & + & - & - & - & + & + & + & + & + & + & + & - \\
\hline CP79 & - & + & + & + & - & - & + & + & - & - & - & - & + & + & + & + & + & + & + & - \\
\hline CP82 & - & + & + & + & - & - & + & + & - & - & - & - & + & + & + & + & + & + & + & + \\
\hline CP84 & - & + & + & + & + & - & + & + & - & - & - & - & - & - & + & + & + & + & + & + \\
\hline CP97 & - & + & + & + & + & - & + & + & - & - & - & - & - & + & - & + & + & + & + & + \\
\hline CP98 & - & + & + & + & + & - & + & + & - & - & - & - & + & + & + & + & + & + & + & + \\
\hline CP99 & - & - & + & + & - & - & + & + & - & - & - & - & + & + & + & + & + & + & + & + \\
\hline CP100 & - & - & + & + & - & - & + & - & - & - & - & - & + & + & + & + & + & + & + & + \\
\hline CP105 & - & - & + & + & - & - & + & + & - & - & - & - & - & - & - & + & + & + & + & + \\
\hline CP109 & - & - & + & + & - & - & + & + & - & - & - & - & - & - & - & + & + & + & + & + \\
\hline CP113 & - & - & + & + & - & - & + & + & - & - & - & - & - & - & - & + & + & + & + & + \\
\hline Cp123 & - & - & + & + & - & - & + & + & - & - & - & + & - & + & - & + & + & + & + & + \\
\hline Cp125 & - & - & + & + & - & - & + & + & - & - & - & + & + & + & + & + & + & + & + & - \\
\hline Cp126 & - & - & + & + & - & - & + & + & - & - & - & + & + & + & + & + & + & + & - & - \\
\hline Cp130 & - & - & + & + & - & - & + & + & - & - & - & - & + & + & + & + & + & + & - & - \\
\hline Cp132 & - & - & + & + & - & - & + & + & - & - & - & - & + & + & + & + & + & + & - & - \\
\hline Cp133 & - & - & + & + & - & - & + & + & - & - & - & - & - & + & + & + & + & + & - & - \\
\hline
\end{tabular}




\begin{tabular}{|c|c|c|c|c|c|c|c|c|c|c|c|c|c|c|c|c|c|c|c|c|}
\hline Cp134 & - & - & + & + & - & - & + & + & - & - & - & - & - & - & + & + & + & + & - & - \\
\hline Cp135 & - & - & + & + & - & - & + & - & - & - & - & - & - & + & + & + & + & + & - & - \\
\hline Cp136 & - & + & + & + & + & - & + & + & - & - & - & + & - & + & + & + & + & + & - & - \\
\hline Cp139 & - & + & + & + & - & - & + & + & - & - & - & - & - & - & + & + & + & + & - & - \\
\hline Cp140 & - & + & + & + & + & - & + & + & - & + & - & - & + & + & + & + & + & + & + & + \\
\hline Cp143 & - & + & + & + & - & - & + & + & + & + & + & - & + & + & + & + & + & + & + & + \\
\hline Cp148 & - & + & + & + & - & - & + & + & - & - & - & - & - & + & + & + & + & + & + & + \\
\hline Cp150 & - & + & + & + & + & - & + & + & + & - & + & - & - & + & + & + & + & + & + & + \\
\hline Cp151 & - & - & + & + & - & - & + & + & + & - & - & - & - & + & + & + & + & + & + & + \\
\hline $\begin{array}{c}\text { HAMBI } \\
1129\end{array}$ & - & - & - & + & - & - & + & + & - & - & - & - & + & + & + & + & + & + & + & + \\
\hline $\begin{array}{c}\text { HAMBI } \\
2148\end{array}$ & - & - & - & + & - & - & - & - & - & - & - & + & + & + & + & + & + & + & + & + \\
\hline $\begin{array}{c}\text { HAMBI } \\
12\end{array}$ & - & - & - & + & - & - & + & + & - & - & - & + & + & + & + & + & + & + & + & + \\
\hline $\begin{array}{c}\text { HAMBI } \\
2314\end{array}$ & - & - & - & + & - & - & + & + & - & - & - & - & + & + & + & + & + & + & + & + \\
\hline $\begin{array}{c}\text { HAMBI } \\
2096\end{array}$ & - & + & + & + & - & - & + & + & - & - & - & + & + & + & + & + & + & - & - & - \\
\hline $\begin{array}{c}\text { HAMBI } \\
2409\end{array}$ & - & + & + & + & - & - & + & - & - & - & - & - & + & + & + & + & + & - & - & - \\
\hline
\end{tabular}


Table S2.2 Carbohydrate Utilization Test of the chickpea isolates

\begin{tabular}{|c|c|c|c|c|c|c|c|c|c|c|c|c|c|c|c|c|c|c|c|}
\hline $\begin{array}{l}0 \\
0 \\
0 \\
0 \\
\frac{0}{0} \\
0 \\
0\end{array}$ & 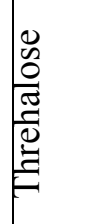 & 声 & 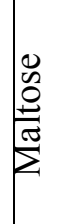 & 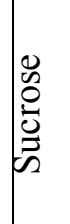 & $\begin{array}{l}0 \\
\begin{array}{l}0 \\
0 \\
0 \\
⿱ 亠 乂\end{array} \\
\end{array}$ & 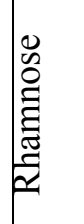 & 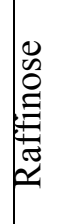 & 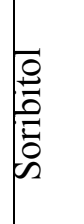 & 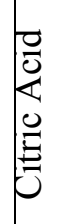 & 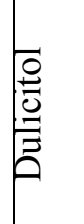 & 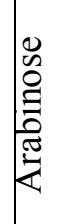 & 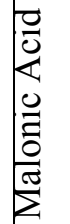 & 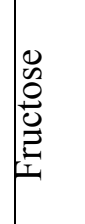 & 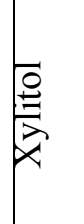 & 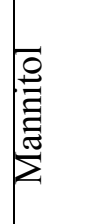 & 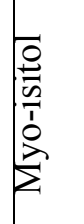 & 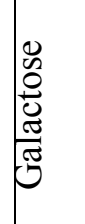 & $\frac{\equiv}{0}$ & 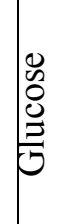 \\
\hline CP01 & + & + & + & + & - & + & + & + & - & + & + & - & + & + & + & + & + & + & + \\
\hline CP06 & + & + & + & + & - & + & + & + & - & + & + & - & + & + & + & + & + & - & + \\
\hline CP08 & + & + & + & + & - & + & + & + & - & + & + & - & + & + & + & + & + & + & + \\
\hline CP10 & + & + & + & + & - & + & + & + & - & + & + & - & + & + & + & + & + & + & + \\
\hline CP12 & + & + & + & + & - & + & - & + & - & + & + & - & + & - & + & + & + & + & + \\
\hline CP19 & + & + & + & + & + & + & - & + & - & + & + & - & + & - & + & + & + & - & + \\
\hline CP20 & + & + & + & + & - & + & - & - & - & + & - & - & + & - & + & + & + & - & + \\
\hline CP27 & + & + & - & + & - & + & - & + & - & + & - & - & + & - & + & + & + & - & + \\
\hline CP30 & + & + & + & + & - & + & - & + & - & + & - & + & + & - & + & + & + & - & + \\
\hline CP41 & + & + & - & + & - & + & - & + & - & + & - & + & + & - & + & + & + & - & + \\
\hline CP44 & + & + & + & + & + & + & + & + & - & + & + & + & + & - & + & + & + & - & + \\
\hline CP49 & + & + & + & + & - & - & + & + & - & + & - & - & + & - & + & + & + & + & + \\
\hline CP51 & + & + & + & + & - & - & - & + & - & + & - & + & + & - & + & + & + & - & + \\
\hline CP61 & + & - & + & + & + & + & + & + & - & + & + & + & + & - & + & + & + & - & + \\
\hline CP65 & + & + & + & + & + & + & + & + & - & + & + & + & + & - & + & + & + & + & + \\
\hline СР69 & + & + & + & + & + & + & + & + & - & + & + & + & + & - & + & + & + & + & + \\
\hline CP74 & + & - & + & + & + & + & + & + & - & + & + & + & + & - & + & + & + & - & + \\
\hline CP79 & + & + & - & + & + & - & - & + & - & - & - & - & + & - & + & + & + & - & + \\
\hline CP82 & + & + & - & + & + & - & - & + & - & + & - & - & + & - & + & + & + & - & + \\
\hline CP84 & + & + & + & + & + & + & - & + & - & + & + & - & + & - & + & + & + & - & + \\
\hline CP97 & + & + & + & + & + & + & - & + & - & + & - & - & + & + & + & - & + & + & + \\
\hline CP98 & + & + & + & + & + & + & - & + & - & + & - & - & + & + & + & - & + & + & + \\
\hline CP99 & + & + & + & + & + & + & - & + & - & + & + & - & + & + & + & + & + & + & + \\
\hline CP100 & + & + & + & + & + & + & + & + & - & + & + & - & + & + & + & + & + & + & + \\
\hline CP105 & + & + & + & + & + & + & - & + & - & + & + & - & + & - & + & + & + & - & + \\
\hline CP109 & + & + & + & + & + & + & - & + & - & + & + & - & + & - & + & + & + & - & + \\
\hline CP113 & + & - & + & + & + & + & - & + & - & + & + & - & + & - & + & + & + & - & + \\
\hline Cp123 & + & - & - & + & + & + & - & + & - & + & + & - & + & - & + & + & + & - & + \\
\hline Cp125 & + & - & - & + & + & + & - & + & - & + & + & - & + & - & + & + & + & - & + \\
\hline Cp126 & + & + & + & + & + & + & + & + & - & + & + & - & + & + & + & + & + & + & + \\
\hline Cp130 & + & + & + & + & + & + & + & + & - & + & - & - & + & + & + & + & + & + & + \\
\hline Cp132 & + & + & - & + & + & - & - & + & - & - & - & - & + & + & + & + & + & - & + \\
\hline Cp133 & + & + & - & + & + & + & - & + & - & - & - & - & - & - & + & + & + & - & + \\
\hline Cp134 & + & + & - & + & + & - & + & - & - & + & - & - & + & - & + & + & + & - & + \\
\hline Cp135 & + & - & + & + & + & - & + & + & - & + & - & - & + & + & + & + & + & - & + \\
\hline Cp136 & + & + & - & + & + & + & - & + & - & + & + & - & + & - & + & + & + & - & + \\
\hline
\end{tabular}




\begin{tabular}{|c|c|c|c|c|c|c|c|c|c|c|c|c|c|c|c|c|c|c|c|}
\hline Cp139 & + & - & - & + & + & - & - & - & - & + & - & - & + & - & + & - & + & - & + \\
\hline $\mathrm{Cp} 140$ & + & + & - & + & + & - & - & + & - & + & - & - & + & + & + & + & + & - & + \\
\hline Cp143 & + & + & - & + & + & + & - & + & - & + & - & - & + & + & + & + & + & - & + \\
\hline Cp150 & + & + & - & + & + & + & + & + & - & + & + & - & + & + & + & + & + & - & + \\
\hline Cp151 & + & + & + & + & + & + & + & + & - & + & + & - & + & + & + & + & + & - & + \\
\hline $\begin{array}{l}\text { HAMBI2 } \\
148\end{array}$ & + & + & + & + & + & + & + & + & - & + & + & - & + & - & + & + & + & - & + \\
\hline $\begin{array}{l}\text { HAMBI1 } \\
2\end{array}$ & + & + & + & + & + & + & + & + & - & + & + & - & + & + & + & + & + & - & + \\
\hline $\begin{array}{l}\text { HAMBI2 } \\
096\end{array}$ & + & + & + & + & + & + & + & + & - & - & + & - & - & + & + & + & - & + & + \\
\hline $\begin{array}{l}\text { HAMBI2 } \\
409\end{array}$ & + & + & + & + & + & + & + & + & - & + & + & - & - & + & + & + & + & + & - \\
\hline
\end{tabular}


Table S2.3. Nitrogen Source Utilization and phosphate solubilization test of the chickpea isolates

\begin{tabular}{|c|c|c|c|c|c|c|c|c|c|c|c|c|c|c|c|c|c|c|}
\hline $\begin{array}{l}0 \\
0 \\
0 \\
0 \\
\frac{0}{\pi} \\
0 \\
0 \\
0\end{array}$ & 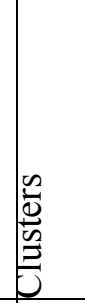 & Ð & 电 & 包 & 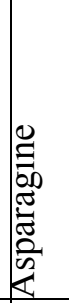 & 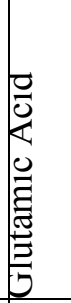 & 己 & 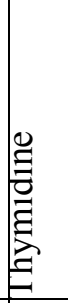 & 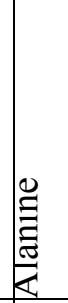 & 兽 & 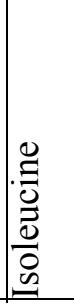 & 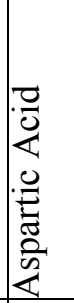 & 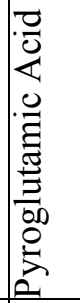 & $\underset{\Xi}{\varrho}$ & 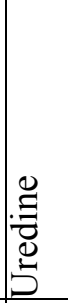 & 芑 & 异 & 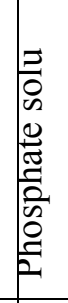 \\
\hline CP01 & I & + & + & + & + & + & + & + & + & + & + & + & + & + & - & + & + & - \\
\hline CP06 & I & + & + & + & + & + & + & + & - & + & + & + & + & + & - & + & + & - \\
\hline CP08 & I & + & + & + & + & + & + & + & + & + & + & + & + & + & + & + & + & - \\
\hline CP10 & I & + & + & + & + & + & + & + & + & + & + & + & + & + & + & + & + & - \\
\hline CP12 & I & + & + & + & + & + & + & + & + & - & + & + & + & + & + & + & + & - \\
\hline CP19 & I & + & + & + & + & + & - & + & + & + & + & + & + & + & + & + & + & - \\
\hline CP20 & I & + & + & + & + & + & - & + & + & + & + & + & + & + & + & + & + & - \\
\hline CP27 & I & + & + & + & + & + & + & + & + & + & + & + & + & + & + & + & + & - \\
\hline CP30 & I & + & + & + & + & + & + & + & + & + & + & + & + & + & + & + & + & - \\
\hline CP41 & I & + & + & + & + & + & + & + & + & + & + & + & + & + & + & + & + & - \\
\hline CP44 & I & + & + & + & + & + & - & + & + & + & + & + & + & + & + & + & + & - \\
\hline CP49 & I & + & + & + & + & + & + & + & + & + & + & + & + & + & + & + & + & - \\
\hline CP51 & I & + & + & + & + & + & + & + & + & + & + & + & + & + & - & + & + & - \\
\hline CP61 & III & + & + & + & + & + & + & + & + & + & + & + & + & + & + & + & + & - \\
\hline CP65 & I & + & + & + & + & + & + & + & + & + & + & + & + & + & + & + & + & - \\
\hline CP69 & I & + & + & + & + & + & + & + & + & + & + & + & + & + & + & + & + & - \\
\hline CP74 & IV & + & + & + & + & + & + & + & + & + & + & + & + & + & + & + & + & - \\
\hline CP79 & I & + & + & + & + & + & + & + & + & + & + & + & + & + & - & + & + & + \\
\hline CP82 & I & + & + & + & + & + & + & + & + & + & + & + & + & + & - & + & + & + \\
\hline CP84 & $\mathrm{I}$ & + & + & + & + & + & + & + & + & + & + & + & - & + & + & + & + & + \\
\hline CP97 & $\mathrm{I}$ & + & + & + & + & + & + & + & + & - & - & + & - & + & - & + & + & - \\
\hline CP98 & II & + & + & + & + & + & + & + & + & - & - & + & - & + & - & + & + & - \\
\hline CP99 & IV & + & + & + & + & + & + & + & + & + & + & + & + & + & + & + & + & - \\
\hline CP100 & IV & + & + & + & + & + & + & + & + & + & + & + & + & + & + & + & + & + \\
\hline CP105 & I & + & + & + & + & + & + & + & + & + & + & + & + & + & + & + & + & + \\
\hline CP109 & I & + & + & + & + & + & + & + & + & + & + & + & + & + & + & + & + & - \\
\hline CP113 & I & + & + & + & + & + & + & + & + & - & - & - & - & + & - & + & + & - \\
\hline Cp123 & I & + & + & + & + & + & + & + & + & + & + & + & + & + & + & + & + & + \\
\hline Cp125 & II & + & + & + & + & + & + & + & + & + & + & + & + & + & + & + & + & - \\
\hline Cp126 & III & + & + & + & + & + & + & + & + & + & + & + & + & + & + & + & + & - \\
\hline Cp130 & III & + & + & + & + & + & + & + & + & + & + & + & + & + & + & + & + & - \\
\hline Cp132 & $\mathrm{I}$ & + & + & + & + & + & + & + & + & + & + & + & + & + & + & + & + & - \\
\hline Cp133 & I & + & + & + & + & + & + & + & + & + & + & + & + & + & + & + & + & + \\
\hline Cp134 & I & + & + & + & + & + & + & + & + & + & + & + & + & + & - & + & + & + \\
\hline Cp135 & $\mathrm{I}$ & + & + & + & + & + & + & + & + & + & + & + & + & + & - & + & + & + \\
\hline
\end{tabular}




\begin{tabular}{|c|c|c|c|c|c|c|c|c|c|c|c|c|c|c|c|c|c|c|}
\hline Cp136 & II & + & + & + & + & + & + & + & + & + & + & + & + & + & + & + & + & + \\
\hline Cp139 & I & + & + & + & + & + & + & + & + & + & + & + & + & + & - & + & + & + \\
\hline Cp140 & I & + & + & + & + & + & + & + & + & + & + & + & + & + & + & + & + & + \\
\hline Cp143 & III & + & + & + & + & + & + & + & + & + & + & + & + & + & + & + & + & + \\
\hline Cp148 & $\mathrm{I}$ & + & + & + & + & + & + & + & + & + & + & + & + & + & + & + & + & + \\
\hline Cp150 & III & + & + & + & + & + & + & + & + & + & + & + & + & + & + & + & + & + \\
\hline Cp151 & III & + & + & + & + & + & + & + & + & + & + & + & + & + & + & + & + & + \\
\hline HAMBI 1129 & II & - & + & + & + & + & + & + & + & + & + & + & + & + & + & + & + & - \\
\hline HAMBI 2148 & $\begin{array}{l}\mathrm{U} \\
\mathrm{C}\end{array}$ & - & + & + & + & + & + & + & + & + & + & + & + & + & + & + & + & - \\
\hline HAMBI 12 & III & - & + & + & + & + & + & + & + & + & + & + & + & + & + & + & + & - \\
\hline HAMBI 2314 & $\begin{array}{l}\mathrm{U} \\
\mathrm{C}\end{array}$ & - & + & + & + & + & + & + & + & + & + & + & + & + & + & + & + & - \\
\hline HAMBI 2096 & II & - & + & + & + & + & + & + & + & + & + & - & + & + & + & + & + & - \\
\hline HAMBI 2409 & III & + & + & + & + & + & + & + & + & + & + & - & + & + & + & + & + & - \\
\hline
\end{tabular}


Table S2.4. Intrinsic Antibiotic and Heavy Metal Resistance $(\mu \mathrm{g} / \mathrm{ml})$ of the chickpea Isolates

\begin{tabular}{|c|c|c|c|c|c|c|c|c|c|c|c|c|c|c|c|c|c|c|c|c|c|c|}
\hline \multirow{3}{*}{$\begin{array}{l}\frac{0}{0} \\
0 \\
0 \\
\frac{\Xi}{0} \\
0 \\
0\end{array}$} & \multicolumn{15}{|c|}{ Antibiotics Resistance } & \multicolumn{7}{|c|}{ Heavy Metal Resistance } \\
\hline & \multicolumn{2}{|c|}{$\overline{0}$} & \multicolumn{2}{|c|}{ 至 } & \multicolumn{2}{|l|}{ 竞 } & \multicolumn{2}{|c|}{$\begin{array}{l}0 \\
\text { ڤn }\end{array}$} & \multirow{2}{*}{ 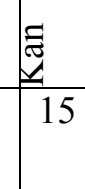 } & \multirow{2}{*}{\multicolumn{2}{|c|}{ 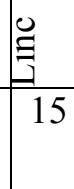 }} & & \multicolumn{2}{|c|}{$\stackrel{8}{Z}$} & \multirow{2}{*}{$\mid \begin{array}{c}z \\
z \\
\end{array}$} & \multirow{2}{*}{\multicolumn{2}{|c|}{$E$}} & \multirow[b]{2}{*}{ 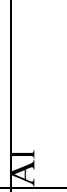 } & \multirow[b]{2}{*}{2} & \multirow[b]{2}{*}{ e } & \multirow[b]{2}{*}{$\vec{\Xi}$} & \multirow[b]{2}{*}{$\vec{\Xi}$} \\
\hline & 5 & 15 & 10 & 20 & 40 & 80 & 250 & 500 & & & & & 5 & 20 & & & & & & & & \\
\hline CP01 & + & - & + & + & - & - & - & - & + & . & & + & + & + & - & & 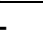 & - & - & - & - & - \\
\hline CP06 & + & - & + & + & - & - & - & - & + & 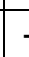 & & + & + & + & - & & - & - & - & - & - & - \\
\hline CP08 & + & - & + & + & - & - & - & - & + & - & & + & + & + & - & & - & - & - & - & - & - \\
\hline CP10 & + & - & + & + & - & - & - & - & + & - & & + & + & + & - & & - & - & - & - & - & - \\
\hline CP12 & + & - & + & + & - & - & - & - & + & . & & + & + & + & + & & - & - & - & - & - & - \\
\hline CP19 & + & - & + & + & - & - & - & - & + & - & & + & + & + & - & & - & - & + & - & - & - \\
\hline CP20 & + & - & + & + & - & - & - & - & + & 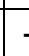 & & + & + & + & - & & - & + & - & - & - & - \\
\hline CP27 & + & - & + & + & - & - & - & - & + & - & & + & + & + & - & & - & - & - & - & - & - \\
\hline CP30 & + & + & + & + & - & - & - & - & - & 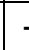 & & + & + & + & + & & - & - & - & - & - & - \\
\hline CP41 & + & + & + & + & - & - & - & - & - & . & & + & + & + & + & & - & - & + & + & - & - \\
\hline CP44 & + & + & + & + & - & - & - & - & - & - & & + & + & + & - & & - & - & - & + & - & - \\
\hline CP49 & + & + & + & + & - & - & - & - & + & 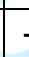 & & + & + & + & - & & - & - & - & + & - & - \\
\hline CP51 & + & + & + & + & - & - & - & - & - & . & & + & + & + & - & & 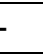 & + & - & + & - & - \\
\hline CP61 & + & + & + & + & - & - & - & - & - & 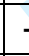 & & + & + & + & + & & + & + & + & + & - & - \\
\hline CP65 & + & - & + & + & - & - & - & - & - & - & & + & + & + & - & & - & - & - & - & - & - \\
\hline CP69 & + & - & + & + & - & - & - & - & - & 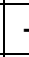 & & - & + & + & - & & - & - & + & + & - & - \\
\hline CP74 & + & + & + & + & - & - & - & - & - & 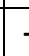 & & + & + & + & + & & + & + & + & + & - & - \\
\hline CP79 & + & + & + & + & - & - & - & - & - & . & & + & + & + & - & & - & - & + & + & - & - \\
\hline CP82 & + & + & + & + & - & - & - & - & + & . & & + & + & + & + & & - & - & + & - & - & - \\
\hline CP84 & + & - & + & + & - & - & - & - & + & - & & + & + & + & - & & - & - & - & - & - & - \\
\hline CP97 & + & + & + & + & - & - & - & - & - & 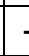 & & + & + & + & + & & + & + & + & + & + & - \\
\hline CP98 & + & + & + & + & - & - & - & - & - & 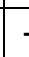 & & + & + & + & + & & + & + & + & + & + & - \\
\hline CP99 & + & + & + & + & - & - & - & - & - & . & & + & + & + & + & & + & - & + & + & - & - \\
\hline CP100 & + & + & + & + & - & - & - & - & - & . & & + & + & + & + & & + & - & + & + & - & - \\
\hline CP105 & + & - & + & + & - & - & - & - & + & - & & + & + & + & - & & - & - & - & - & - & - \\
\hline CP109 & + & - & + & + & - & - & - & - & + & . & & + & + & + & - & & - & - & - & - & - & - \\
\hline CP113 & + & + & + & + & - & - & - & - & + & . & & + & + & + & - & & + & - & + & + & - & - \\
\hline Cp123 & + & + & + & + & - & - & - & - & + & 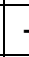 & & + & + & + & - & & - & + & - & - & - & - \\
\hline Cp125 & + & + & + & + & - & - & - & - & + & . & & + & + & + & - & & - & + & - & - & - & - \\
\hline Cp126 & + & + & + & + & - & - & - & - & + & - & & - & + & + & + & & 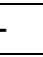 & + & - & - & - & - \\
\hline Cp130 & + & + & + & + & - & - & - & - & - & 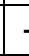 & & + & + & + & + & & - & + & - & + & - & - \\
\hline Cp132 & + & + & + & + & - & - & - & - & - & - & & + & + & + & - & & - & + & - & - & - & - \\
\hline Cp133 & + & - & + & + & - & - & - & - & + & - & & + & + & + & - & & + & - & - & - & - & - \\
\hline Cp134 & - & - & + & + & - & - & - & - & + & . & & - & + & + & + & & - & - & - & + & + & - \\
\hline Cp135 & + & + & + & + & - & - & - & - & - & . & & - & + & + & & & - & + & - & - & - & - \\
\hline Cp136 & + & + & + & + & - & - & - & - & + & . & & + & + & + & - & & - & + & - & - & - & - \\
\hline
\end{tabular}




\begin{tabular}{|c|c|c|c|c|c|c|c|c|c|c|c|c|c|c|c|c|c|c|c|c|}
\hline Cp139 & + & - & + & + & - & - & - & - & + & - & - & + & + & + & + & - & - & - & - & - \\
\hline Cp140 & + & + & + & + & - & - & - & - & - & - & - & + & + & + & - & + & - & + & - & - \\
\hline Cp143 & + & + & + & + & - & - & - & - & + & - & - & + & + & + & - & + & - & + & + & - \\
\hline Cp148 & + & + & + & + & - & - & - & - & + & - & - & + & + & - & - & - & - & - & - & - \\
\hline Cp150 & + & + & + & + & - & - & - & - & + & - & - & + & + & + & + & + & - & + & - & - \\
\hline Cp151 & + & + & + & + & - & - & - & - & + & - & - & + & + & + & + & + & - & + & - & - \\
\hline $\begin{array}{l}\text { HAMBI } \\
1129\end{array}$ & + & - & + & + & - & - & - & - & + & - & - & + & + & - & - & - & - & + & - & - \\
\hline $\begin{array}{l}\text { HAMBI } \\
2148\end{array}$ & + & + & + & - & - & - & - & - & - & - & - & + & + & + & + & + & + & + & + & - \\
\hline $\begin{array}{l}\text { HAMBI } \\
12\end{array}$ & + & + & + & - & - & - & - & - & - & - & - & + & + & + & + & + & + & + & + & - \\
\hline $\begin{array}{l}\text { HAMBI } \\
2314\end{array}$ & + & + & + & - & - & - & - & - & + & - & - & + & + & + & + & + & + & + & + & - \\
\hline $\begin{array}{l}\text { HAMBI } \\
2096\end{array}$ & + & + & - & - & - & - & + & + & + & + & + & + & + & + & + & - & - & + & + & + \\
\hline $\begin{array}{l}\text { HAMBI } \\
2409\end{array}$ & - & - & + & + & + & + & - & - & - & + & + & - & - & - & - & - & + & + & + & + \\
\hline
\end{tabular}




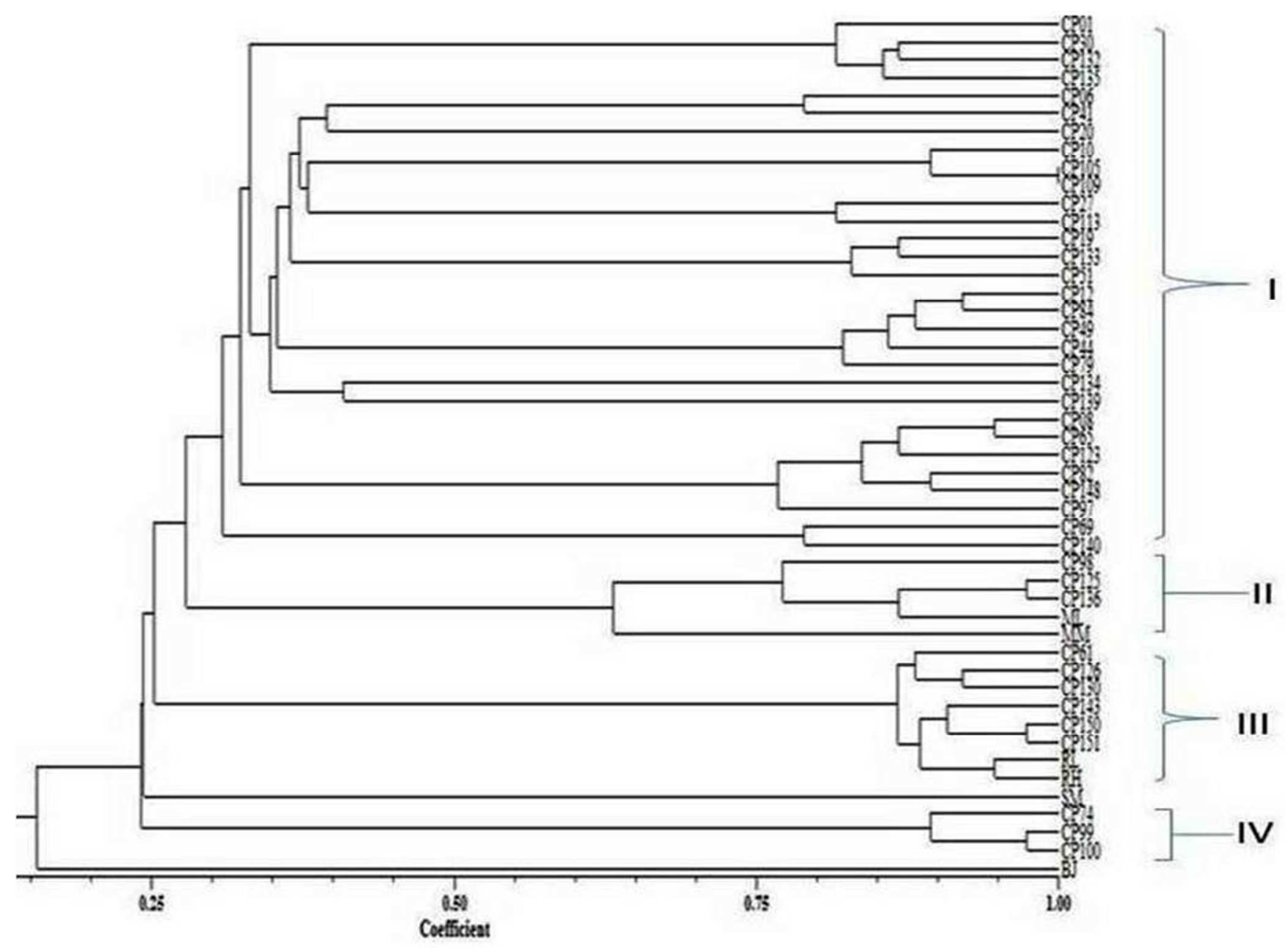

Figure S1. Dendrogram highlighting the phenotypic similarities among rhizobial strains isolated from chickpeas from different areas of Ethiopia. Numbers I, II, III and IV denote the phenotypic clusters. The reference strains are: ML: Mesorhizobium loti HAMBI (1129T), EM: Ensifer meliloti (HAMBI 2148T), RL: Rhizobium leguminosarum (HAMBI 12T), BJ: Bradyrhizobium japonicum (HAMBI 2314T), MM: M. mediterraneum (HAMBI 2096T) and RH: Rhizobium huautlense (HAMBI 2409T). 